\title{
Liquid Storage of Ram Semen: Associated Damages and Improvement
}

\author{
Serge Leugoué Kameni ${ }^{\circledR}$, Félix Meutchieye, Ferdinand Ngoula \\ Department of Animal Science, Faculty of Agronomy and Agricultural Science, University of Dschang, Dschang, Cameroon \\ Email: ferdinand.ngoula@univ-dschang.org
}

How to cite this paper: Kameni, S.L., Meutchieye, F. and Ngoula, F. (2021) Liquid Storage of Ram Semen: Associated Damages and Improvement. Open Journal of Animal Sciences, 11, 473-500. https://doi.org/10.4236/ojas.2021.113033

Received: May 12, 2021

Accepted: July 13, 2021

Published: July 16, 2021

Copyright $\odot 2021$ by author(s) and Scientific Research Publishing Inc. This work is licensed under the Creative Commons Attribution International License (CC BY 4.0).

http://creativecommons.org/licenses/by/4.0/ Open Access

\begin{abstract}
The successful application of assisted reproductive techniques (ARTs) in ovine as in other mammal species relies on many factors among which the quality of the semen used. After collection, semen samples are generally processed for storage (liquid storage or cryoconservation) before being used for insemination or in vitro embryo production. During the liquid storage process, sperm cells are exposed to artificial conditions which lead to oxidative stress-the imbalance between pro-oxidants and antioxidants (AO), following overproduction of reactive oxygen species (ROS) - resulting in ultrastructural, biochemical and functional damages of spermatozoa. Especially, viability, motility, mitochondrial activity, membrane integrity, and acrosome integrity are reduced while morphological abnormalities, DNA fragmentation, and lipid peroxidation (LPO) are increased, affecting the fertilizing ability and subsequent early embryonic development when using standard extenders. Indeed, an optimal semen extender must not only regulate and support an environment of adequate $\mathrm{pH}$ and buffering capacity to protect spermatozoa from osmotic and cooling stresses, but, also prevent the generation and/or scavenge excess ROS. To improve ram semen liquid storage, several methods have been developed with the supplementation of extenders with antioxidants or antioxidant like-compounds (enzymes, amino-acids, vitamins, plant extracts), seminal plasma, sugars, fatty acids, and nanoparticles being a relevant approach. Promising results have been registered with the supplementation of extenders with these compounds, confirming they can be used to preserve ram semen quality and fertility. Therefore, the present review provides an updated overview of the damages and associated mechanisms that ram spermatozoa undergo during liquid storage. Moreover, the supplementation of extenders with different compounds as a tool to improve semen storage is also discussed as well as their efficiency to reduce and/or prevent sperm damages during storage.
\end{abstract}




\section{Keywords}

Antioxidants, Lipid Peroxidation, Liquid Storage, Ovine, Oxidative Stress, Reactive Oxygen Species

\section{Introduction}

In sheep farming, high feed price can be seen as an advantage for ovine since they have a better ability to convert fibrous, low quality feedstuffs into meat and other products than cattle. In this field, the optimization of reproduction is achieved by the means of assisted reproductive techniques (ARTs) which include semen collection and storage, estrus synchronization, artificial insemination (AI), in vitro fertilization (IVF), intra-cytoplasmic sperm injection, embryo transfer, multiple ovulation embryo transfer, and juvenile in vitro embryo technology. The success of these different techniques mainly relies on semen quality which depends on the processing and precisely on the ability of the extenders to maintain sperm ultrastructural, biochemical, and functional characteristics [1]. However, as for freeze-thawing, semen liquid storage which consists of decreasing the metabolism rate of sperm cells so that the lifespan of spermatozoa is prolonged, reduces sperm quality and fertility, [1] [2] [3] and this trend is accentuated as the storage time increases [4] [5]. Indeed, it has been highlighted that sperm storage via reactive oxygen species (ROS) over-generation, alters the delicate antioxidants (AO)/pro-oxidants balance, leading to oxidative stress [6] [7] and subsequent lipid peroxidation (LPO). ROS are normal by-products of cell metabolism and in a relatively low amount, play a key role in sperm functions like capacitation, acrosome reaction, and binding to the zona pellucida [8] [9] [10]. Impaired cell functions caused by oxidative stress gradually result in decreased sperm viability, morphological and acrosome integrities and several other sperm parameters, and ultimately lead to the reduction of the fertilization's rate and the consequent decrease in production [11]. Moreover, ram sperm membrane is particularly rich in polyunsaturated fatty acids (PUFAs), making them highly susceptible to cold shock and LPO. Despite the intrinsic antioxidative defense system of sperm cells, AI in sheep is limited by the short functional life of spermatozoa when stored in standard extenders due to the overproduction of ROS and subsequent damages.

To minimize the deleterious effects associated to storage, an optimal semen extender must not only regulate and support an environment of adequate $\mathrm{pH}$ and buffering capacity to protect spermatozoa from osmotic and cooling stresses, but, also prevent the generation and/or scavenge excess ROS. In this regard, several investigations have focused on the ability of different compounds used as additives to semen extenders, to maintain sperm viability, motility, membrane integrity and fertility. Improvements in ram semen quality have been recorded with addition of antioxidants and particularly plant extracts [12] [13] and many other substances including seminal plasma [14], sugars [15], fatty ac- 
ids [16], and nanoparticles [17]. This article reviews the liquid storage-associated damages to ram sperm cells and the supplementation of extenders with different compounds, especially plant extracts to preserve ram sperm quality and fertility.

\section{Effect of Storage on Semen Quality}

When semen samples are stored for extended periods, regardless of the type of diluents used, the specific storage temperature, dilution rate or conditions in which the spermatozoa are stored, they deteriorate (reduced sperm motility, viability, intracellular enzymatic activity) as the period of storage increases [1] [18] [19], resulting in loss of fertility. This is mainly related to the accumulation of toxic products formed from the sperm's metabolism, largely of the ROS-by-products formed during the normal enzymatic reactions of inter- and intracellular signaling comprising radicals (hydroxyl ion, superoxide, nitric oxide, peroxyl, etc.) and non-radicals (ozone, single oxygen, lipid peroxides, hydrogen peroxide) oxygen derivatives [20] — which the generation is amplified by LPO [1], consequent to oxidative stress. Oxidative stress is a normal phenomenon. Under ordinary circumstances, various enzymatic systems involved in the in vivo redox homeostasis regulate the physiologically important intracellular concentrations of ROS at low levels [21]. Therefore, oxidative stress can be viewed as an imbalance between pro-oxidants and antioxidants in favor of the former. Any alteration in homeostasis leads to increased production of these pro-oxidants, much above the detoxifying capacity of the local tissues [22]. The ROS in excess react with other molecules within cells and lead to oxidative damage of proteins, membranes, and genes (Figure 2). Moreover, they often generate more ROS, resulting in a sequence of destruction. In the case of mammalian sperm cells, in which the cellular membrane is particularly rich in PUFAs, oxidative stress mainly leads to LPO, resulting in an irreversible loss in sperm motility, impairment to sperm DNA and fertility [23].

The LPO which consists of initiation, propagation and termination steps, can be described as a process under which oxidants such as free radicals or non-radical species attack lipids containing carbon-carbon double bond(s), especially PUFAs that involve hydrogen abstraction from a carbon, with oxygen insertion resulting in lipid peroxyl radicals and hydroperoxides [24].

In the LPO initiation step, pro-oxidants like hydroxyl radical abstract the allylic hydrogen forming the carbon-centered lipid radical $\left(L^{\circ}\right)$. In the propagation phase, lipid radical $\left(\mathrm{L}^{\cdot}\right)$ rapidly reacts with oxygen to form a lipid peroxy radical (LOO*) which abstracts a hydrogen from another lipid molecule generating a new $\mathrm{L}^{\cdot}$ (that stimulates the chain reaction) and lipid hydroperoxide ( $\left.\mathrm{LOOH}\right)$. In the termination reaction, antioxidants like vitamin $\mathrm{E}$ donate a hydrogen atom to the LOO' species and form a corresponding vitamin $\mathrm{E}$ radical that reacts with another LOO• forming non-radical products (Figure 1). Once LPO is initiated, a propagation of chain reactions will take place until termination products are formed.

Moreover, mammalian semen has an inherently insufficient antioxidant system to protect sperm cells against the deleterious effects of oxidative stress dur- 
ing semen processing and storage [25]. Sperm cells are extremely susceptible to low temperatures during the cooling or freezing process. This has been attributed to the high concentrations of PUFAs in the plasma membrane of ram sperm [26] that renders the cells particularly sensitive to cold shock as well as to LPO in the presence of ROS [27]. In the same vein, it has been reported that ram sperm susceptibility to LPO may be associated to the impairment of sperm quality [28].

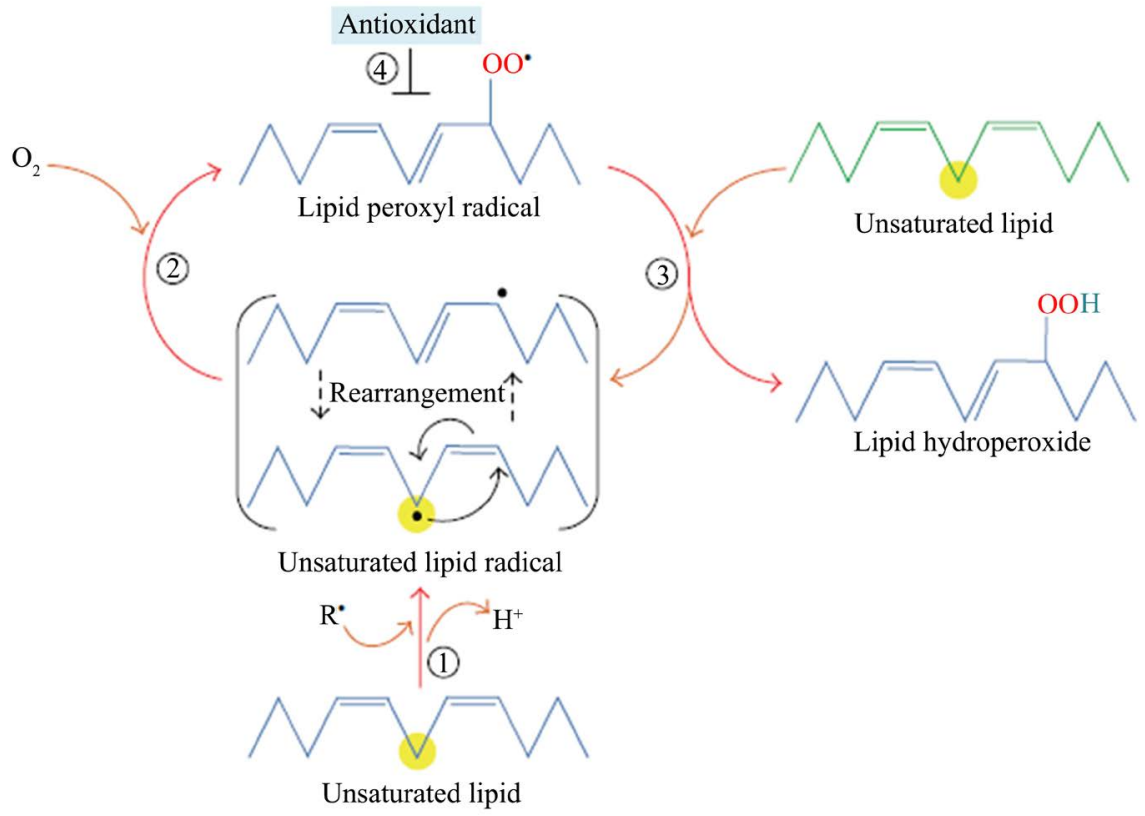

Figure 1. Lipid peroxidation process [29]. In Initiation, pro-oxidants abstract the allylic hydrogen forming the carbon-centered lipid radical; the carbon radical tends to be stabilized by a molecular rearrangement to form a conjugated diene (step 1). In the propagation phase, lipid radical rapidly reacts with oxygen to form a lipid peroxy radical (step 2) which abstracts a hydrogen from another lipid molecule generating a new lipid radical and lipid hydroperoxide (step 3). In the termination reaction, antioxidants donate a hydrogen atom to the lipid peroxy radical species resulting in the formation of non-radical products (step 4).

\subsection{Effect of Liquid Storage on Sperm Parameters}

Semen storage, being in liquid or cryopreserved forms, is generally associated with a decrease in sperm characteristics, thus a loss in fertility [1] [18] (Table 1). As highlighted in Figure 2, the major changes following storage are ultrastructural, biochemical and functional and such alterations consequently lead to impaired transport, decline in survival of spermatozoa in the female reproductive tract and reduced fertility [1] [2].

The sperm membrane is the primary barrier against injury to spermatozoa. Cooling is accompanied by protein changes on the spermatozoa surface and it also has particular effects on lipids and sperm membrane integrity [26]. Fluctuations in temperature and cell dehydration induce specific changes in the lateral-phase separation of lipids and thus a re-ordering of the membrane components and the loss of PUFAs and cholesterol, resulting in increased metabolic activity [30] 
and the stimulation of hyperactivation and capacitation [31]. As indicated in Figure 3, this reorganization impairs the permeability of the spermatozoa surface to water, ions and cryoprotectants [32] and leads to loss of membrane integrity [33] [34].

Table 1. Reduction rate of ram sperm parameters following $48 \mathrm{~h}$ of liquid storage.

\begin{tabular}{|c|c|c|c|c|}
\hline Sperm parameters & Reduction (\%) & Extenders & $\begin{array}{c}\text { Liquid storage } \\
\text { temperature }\left({ }^{\circ} \mathrm{C}\right)\end{array}$ & References \\
\hline Total motility & 72.00 & \multirow{4}{*}{ TFGEY } & \multirow{4}{*}{5} & \multirow{4}{*}{ [35] } \\
\hline Progressive motility & 80.35 & & & \\
\hline Viability & 66.00 & & & \\
\hline Membrane integrity & 64.05 & & & \\
\hline Total motility & 8.82 & \multirow{4}{*}{ TEY } & \multirow{4}{*}{5} & \multirow{4}{*}[36]{} \\
\hline Progressive motility & 17.81 & & & \\
\hline Viability & 34.50 & & & \\
\hline Membrane integrity & 2.08 & & & \\
\hline Acrosome integrity & 20.72 & \multirow{3}{*}{ MG } & \multirow{3}{*}{5} & \multirow{3}{*}{ [37] } \\
\hline Membrane integrity & 16.30 & & & \\
\hline DNA integrity & 31.95 & & & \\
\hline Progressive motility & 41.66 & \multirow{4}{*}{ TCA } & \multirow{4}{*}{4} & \multirow{4}{*}[38]{} \\
\hline Viability & 31.08 & & & \\
\hline Acrosome integrity & 60.96 & & & \\
\hline Membrane integrity & 69.15 & & & \\
\hline Total motility & 41.66 & \multirow{4}{*}{ TCEY } & \multirow{4}{*}{4} & \multirow{4}{*}{ [39] } \\
\hline Viability & 10.66 & & & \\
\hline Acrosome integrity & 42.50 & & & \\
\hline Membrane integrity & 55.40 & & & \\
\hline
\end{tabular}

TFGEY: Tris-fructose-glycerol-egg yolk; TEY: Tris-egg yolk; MG: Milk-glucose; TCA: Tris-citric-acid; TCEY: Tris-citric-egg yolk.

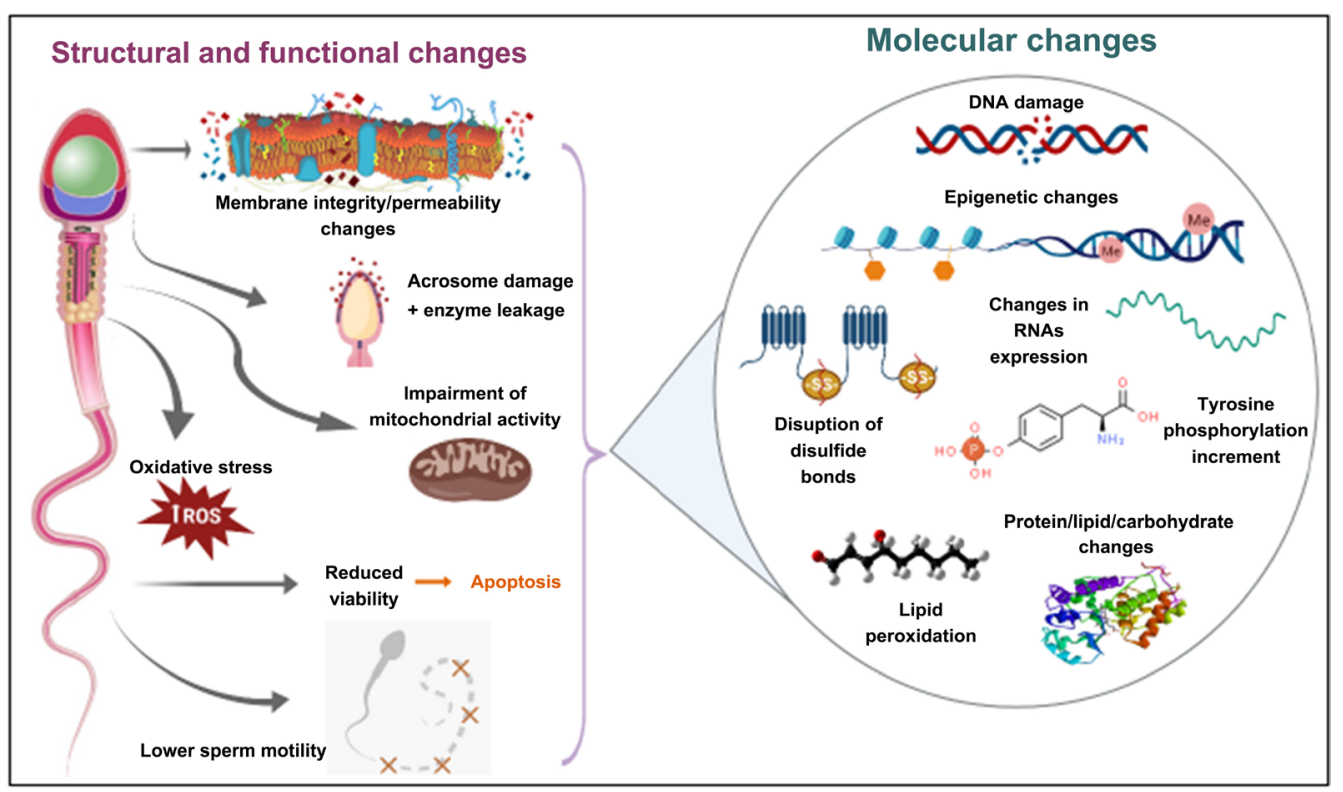

Figure 2. Structural, functional, and molecular changes that ram sperm cells undergo during storage [40]. During the storage process, ram spermatozoa experience several damages which are likely the consequences of molecular changes following overproduction of reactive oxygen species (ROS), thus oxidative stress. 


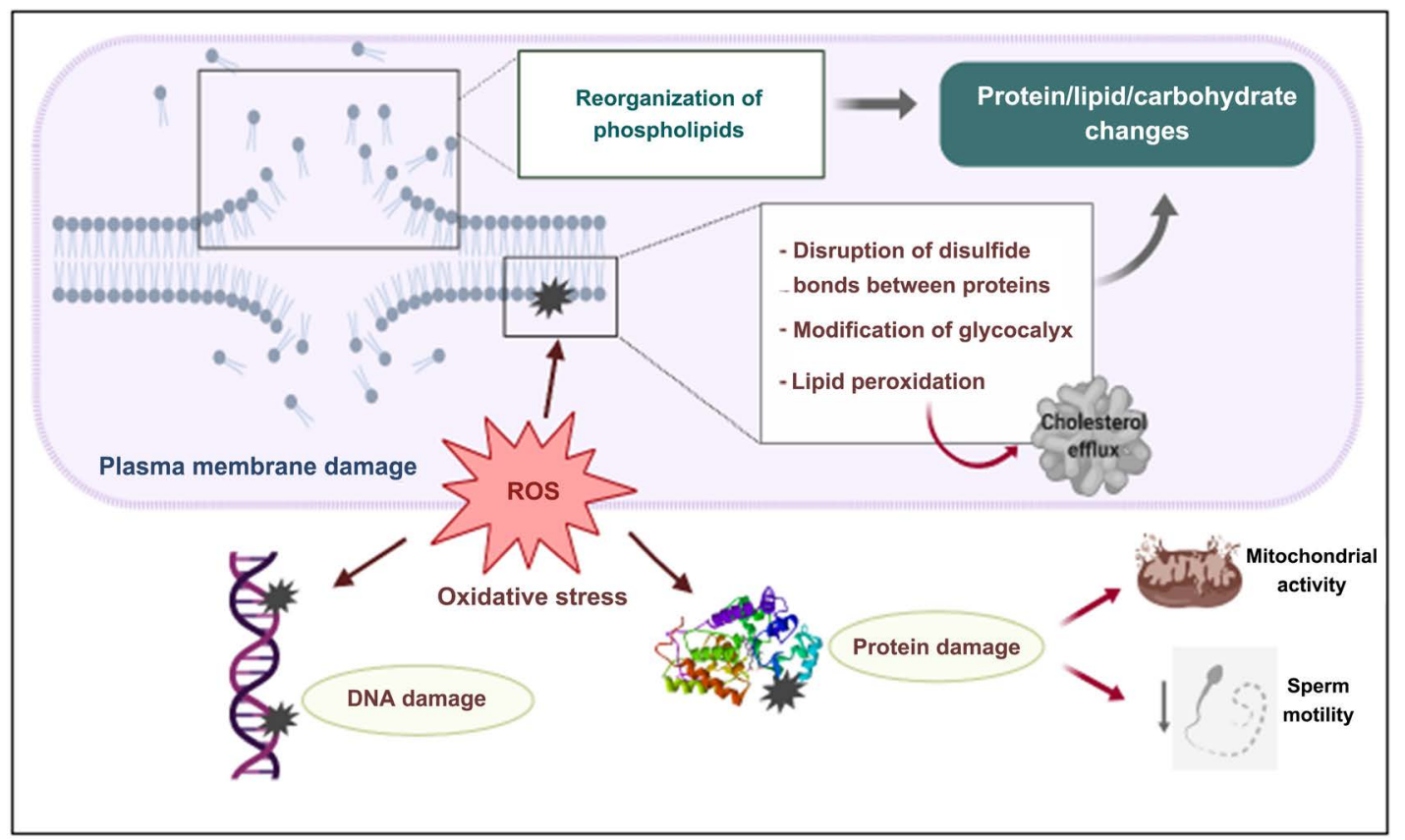

Figure 3. Plasma membrane damage during sperm storage and its relationship with oxidative stress [40]. A re-ordering of sperm membrane phospholipids occurs during temperature changes, altering lipid-protein, lipid-carbohydrate and protein-carbohydrate interactions which are necessary for proper membrane activity. Excessive production of reactive oxygen species (ROS) leads to major protein, lipid and carbohydrate changes in the sperm membrane due to the reduction of disulfide bonds between membrane proteins, peroxidation of membrane phospholipids and modifications of the sperm glycocalyx. As a result, the sperm membrane becomes fragile and its semipermeable property is lost. Overproduction of ROS during sperm storage may also cause DNA damage and impair several axonemal and mitochondrial proteins, which negatively affect mitochondrial activity and axonemal integrity, resulting in the loss of sperm motility.

In routine semen evaluation, sperm motility represents a key parameter as it is positively correlated with sperm fertility and represents a robust indicator of sperm quality, beyond mitochondrial activity and DNA integrity [41]. Indeed, effective ram semen liquid storage is associated to reversible decrease in motility and metabolic activity of sperm cells following cooling at lower temperatures and addition to semen extenders of compounds with the ability to reduce ROS production [42]. The production of ROS arises as a consequence of aerobic conditions where live sperm cells are involved [20]. The accumulation of ROS to high concentrations leads to oxidative stress and subsequent LPO which provokes an irreversible loss of motility and inhibition of fructolysis and respiration in ram spermatozoa [1] [23]. This could be an explanation of the decrease of sperm motility recorded over the storage time [43]. Also, sperm motility is particularly associated with mitochondria activity as mitochondria represent the cell energy generator and concomitantly the major site of intracellular ROS formation, resulting in a disruption of electron transport [44]. This disruption also participates in the decline of motility and amplifies LPO in the spermatozoa membrane [45].

As for motility, ram semen liquid storage is associated with a gradual decrease of sperm viability [46] [47] and such decrease is negatively correlated with LPO 
[45] and can be attributed to the endogenous production of ROS [48].

The integrity of the acrosome is of paramount importance for the fertilization success as it contains several enzymes involved in the fusion of sperm with the oocyte. The subpopulation of cells with intact acrosome decreases with storage [4] [49]. Furthermore, liquid storage results in some spermatozoa being capacitated already, and thus their lifespan within the female tract is shortened significantly [23]. However, it has been reported that while ram sperm cytoplasmic membranes are altered following $96 \mathrm{~h}$ storage at $4^{\circ} \mathrm{C}$, acrosome membranes remain stable and do not undergo any process of early reaction, indicating a different sensitivity of these structures [19].

It has been extensively documented that liquid storage of ram semen, and the inherent oxidative stress, lead to DNA damages which increase as the storage time is prolonged [12] [37] [50]. The functionality of the nuclear structure is essential for the viability and fertilizing ability of spermatozoa and it has been demonstrated that sperm DNA fragmentation is negatively correlated with ejaculate volume, mass activity, motility and membrane integrity following evaluation of fresh ram semen [51]. However, it has been demonstrated that oxidative damages to sperm DNA was not necessarily associated with decreased cell motility or viability, suggesting that a cell with compromised DNA may still achieve fertilization [52].

\subsection{Effect of Liquid Storage on Semen Biochemical Profile}

In general, changes in cellular sperm characteristics are accompanied by changes in semen's biochemical profile. In other to have a broad scope of semen's status, biochemical analyses are performed. These analyses help to understand the potential mechanisms behind the decrease of sperm quality and essentially assess antioxidant and oxidant statuses and LPO throughout storage.

\subsubsection{Antioxidant Status}

Superoxide dismutase (SOD), catalase (CAT), glutathione peroxidase (GPx), and glutathione reductase (GR) are the major antioxidants involved in the detoxification of ROS in mammalian spermatozoa [10]. These enzymatic enzymes work concomitantly to neutralize excess ROS and prevent cellular structure injuries. In the antioxidant protection process, SOD plays a pivotal role in the natural defense against free radicals [53]. It is well known that superoxide ion $\left(\mathrm{O}^{2-}\right)$ is the starting point in the chain production of ROS. At this early stage, SOD inactivates the superoxide ion by transforming it into hydrogen peroxide $\left(\mathrm{H}_{2} \mathrm{O}_{2}\right)$. The latter is then quickly catabolized by CAT and GPx into dioxygen $\left(\mathrm{O}_{2}\right)$ and water $\left(\mathrm{H}_{2} \mathrm{O}\right)$ as shown in the following equation.

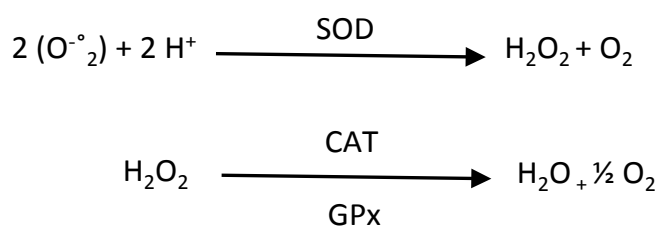


As these enzymatic antioxidants are used to protect sperm cells against oxidative damages, there are synthesized or activated aiming to maintain oxidative homeostasis [28]. However, their activities generally tend to decrease as storage duration is extended [25] [54] [55]. Moreover, the biosynthetic capacity of sperm is limited [56], and the concentration of the antioxidants present in the semen can be reduced by dilution, and as a result decreasing the beneficial effect of these endogenous antioxidative defenses.

\subsubsection{Oxidant Status and LPO}

Previous reports have indicated that the production of pro-oxidants during sperm storage is one of the inevitable phenomena [48] [57]; hydrogen peroxide and nitric oxide being among the most pro-oxidants studied in semen storage.

Hydrogen peroxide is the primary source of ROS responsible for the loss of sperm function since CAT, which selectively degrades this ROS, is the only scavenger to confer complete protection to spermatozoa [58]. Preservation processing of ram semen led to hydrogen peroxide generation, thus decreased sperm quality, however, the addition of CAT to the extender reduced the amount of hydrogen peroxide generated [59].

Free radical with a relatively long half-life $(7 \mathrm{~s})$, nitric oxide inhibits human sperm motility at high concentration $(0.3 \mathrm{mM})$ and induces sperm capacitation at lower concentration $(0.1 \mathrm{mM})$ [8]. Moreover, nitric oxide may inhibit cell respiration by nitrosylation of heme in mitochondrial enzymes, aconitase, and glyceraldehyde phosphate dehydrogenase [20]. It has been well documented that nitric oxide is continuously generated during sperm storage and thus, the subsequent loss in sperm quality [25]. Moreover, the profound impact of oxidative/nitrosative stress on sperm quality during the liquid storage period has been clearly demonstrated, with increasing level of nitric oxide as storage time was extended [57].

Malondialdehyde (MDA) is a key product of PUFAs' peroxidation in the cells [60] and is therefore generally used as an indicator of oxidative damage. MDA concentration, has clearly been shown to be negatively correlated with sperm motility [55]. Several studies have shown that MDA is continuously generated during liquid storage [25] [42], suggesting that the longer the storage, the higher the damages to spermatozoa, thus increasing MDA concentration. Accumulation of the end products of metabolism, which include cytotoxic aldehydes as MDA, amplifies ROS generation and LPO during semen storage. These cytotoxic metabolites, resulting from LPO, triggered apoptotic cascade and cell senescence in spermatozoa [61].

\section{Supplementation of Extenders to Attenuate the Damaging Effect of Ram Semen Liquid Storage}

Despite the advancements achieved in the field of semen storage, there is still a gap to close and the issue remains the designing of an extender able to maintain sperm characteristics as long as possible with the minimum of injuries to cells. 
Considering the high concentration of PUFAs in the plasma membrane of mammalian spermatozoa and the extrusion of the antioxidant-rich cytoplasm of sperm cells during maturation stages, a major part of the research has been focused on the supplementation of extenders with antioxidants and compounds with the potential capacity to reduce storage-associated damages. Indeed, it is well known that the high content of PUFAs in the plasma membrane of spermatozoa combined with the loss of cytoplasm makes spermatozoa of mammalian species extremely susceptible to oxidative stress consequent to ROS overproduction, which leads to poor semen quality and ultimately loss of fertility [23].

To improve liquid storage of ram semen, a battery of measures have been implemented to reduce the damaging effect of semen storage, the major one consisting in the supplementation of the extenders with compounds with the potential ability to better preserve semen's ultrastructure, biochemical status, and functions, and consequently improve fertility after insemination as shown in Table 2 .

Table 2. Summary of noteworthy results on fertility of liquid preserved ram semen with additives after insemination.

\begin{tabular}{llcccc}
\hline Additives & Extenders & Insemination types & Control (\%) & $\begin{array}{c}\text { Improved } \\
\text { fertility (\%) }\end{array}$ & References \\
\hline Hydroxytyrosol & INRA $96^{\circledR}$ & Cervical & 15 & 24 & {$[62]$} \\
Oregonin & TGGEY & Cervical & 60 & 80 & {$[13]$} \\
Mito-TEMPO & TFGEY & Vaginal & 32 & 48 & {$[35]$} \\
Trolox & TCF & Vaginal & 21 & 29 & {$[63]$} \\
GSH & TCF & Vaginal & 21 & 37 & {$[63]$} \\
GSH & EY & Cervical & 76 & 81 & {$[64]$} \\
Ram seminal plasma & TEY & Cervical & 31 & 49 & {$[65]$} \\
SOD and CAT & TGEY & Intra-uterine & 16 & 50 & {$[4]$} \\
\hline
\end{tabular}

Hydroxytyrosol: Olive-oil derived antioxidant; Oregonin: Secondary metabolite extracted from Alnus incana bark; Mito-TEMPO: Mitochondria targeted antioxidant; Trolox: Vitamin E analogue; GSH: Glutathione; SOD: Superoxide dismutase; CAT: Catalase; INRA $96^{\circledR}$ : Commercial brand of a milk-based extender; TGGEY: Tris-glucose-glycerol-egg yolk; TFGEY: Tris-fructose-glycerol-egg yolk; TCF: Tris-citrate-fructose; EY: Egg yolk; TEY: Tris-egg yolk; TGEY: Tris-glucose-egg yolk; Maximum storage duration: 6 h - 14 days; Storage temperature: $5^{\circ} \mathrm{C}$ or $15^{\circ} \mathrm{C}$.

\subsection{Supplementation of Extenders with Antioxidants}

Antioxidants are the compounds and reactions which dispose, scavenge, and suppress the formation of ROS, or oppose their actions [10].

\subsubsection{Enzymes}

Enzymatic antioxidants, which include SOD, CAT, GPx, and GR are macromolecules that protect cells against ROS [66].

The SOD's antioxidant capacity varies according to semen quality [67] as well as during storage processes [68]. These changes in enzyme's activity in semen and the relationship with sperm quality can be ascribed to oxidative stress, because enzymes are utilized in excess to protect or maintain sperm quality, or be- 
cause the enzymes do not have the capacity to maintain sperm quality [67]. Positive results have been reported regarding the inclusion of SOD in extenders. The addition of $800 \mathrm{U} / \mathrm{mL}$ or $150 \mu \mathrm{M}$ of SOD to the extenders provided greater protection, especially for motility, to ram sperm cells submitted to refrigeration [4] [69]. Moreover, the pregnancy rate was greater when inseminating ewes with semen treated with the combination of SOD $(800 \mathrm{U} / \mathrm{ml})$ and CAT $(200 \mathrm{U} / \mathrm{mL})$ and stored up to 14 days in comparison to the control [4].

In the same vein, CAT has been used as an additive to improve the antioxidant capacity of the semen and preserve sperm functions [4] [70]. In this regard, it has been reported that the inclusion of CAT (100 and $200 \mathrm{U} / \mathrm{mL})$ in diluents can prevent the harmful effects of cooling on total motility [33] and ram sperm survival [4] during liquid storage at $5^{\circ} \mathrm{C}$. Nevertheless, concentrations of CAT greater than $200 \mathrm{U} / \mathrm{mL}$ were toxic to the sperm.

Glutathione peroxidases and several ancillary enzymes required for the synthesis and reduction of glutathione (GSH) are involved in the control of cellular peroxide concentrations [71]. It has been reported that GPx acts upon GSH to reduce hydrogen peroxide to $\mathrm{H}_{2} \mathrm{O}$ and lipoperoxides to alkyl alcohols [72]. The GSH subsequently can be regenerated from its oxidized form (GSSG) by GSR, the activity of which is inducible upon oxidative stress.

Although it is a non-enzymatic antioxidant, GSH acts as a coenzyme. The addition of $1-2 \mathrm{mM}$ GSH to ram semen extender enhanced sperm survival and reduced free radicals following $96 \mathrm{~h}$ of chilled storage [73]. A more recent study has confirmed the beneficial effects of GSH during cooled storage at $5^{\circ} \mathrm{C}$ up to $72 \mathrm{~h}$ [36]. The authors concluded that GSH can reduce the decline of sperm total motility, membrane integrity, motion parameters, mitochondrial activity, and the abundance of sperm hexose transporters by enhancing the antioxidant status and energy metabolism of liquid stored ram spermatozoa, the concentration of $200 \mathrm{mM}$ being optimal.

\subsubsection{Vitamins}

Vitamins are partly accountable for semen quality and some of them have been reported to play an important role in preserving semen characteristics and functions [71].

Vitamin $\mathrm{E}$ is the main lipophilic antioxidant that protects PUFAs in tissues against peroxidation. Vitamin $\mathrm{E}$ is a potent peroxyl radical remover and probably the most important inhibitor of the LPO chain reaction in animals [44]. Ram semen quality can be preserved following the addition of different forms of vitamin E (Trolox, alpha-tocopherol) to extenders. Inclusion of vitamin E (1 or 2 $\mathrm{mg}$ ) to the egg yolk-citrate extender improved the motility and sperm membrane integrity of chilled ram semen [74]. Similarly, other authors reported that the addition of vitamin $\mathrm{E}$ preserved the viability and motility of sperm stored at $5{ }^{\circ} \mathrm{C}$ for $120 \mathrm{~h}$ [75] [76]. Further, supplementing ram semen extender during chilled storage with $5 \mathrm{IU}$ Vitamin $\mathrm{E}$ per $\mathrm{mL}$ enhanced sperm survival and reduced free radicals [73]. 
Trolox, a water-soluble analogue of vitamin E, is a chain-breaking antioxidant that functions as a scavenger of lipid peroxyl radicals [77]. Its protective effect against LPO has been reported for ram semen [59]. The use of trolox during liquid storage at $15^{\circ} \mathrm{C}$ of ram semen negatively affects sperm quality, while at $5^{\circ} \mathrm{C}$, such negative effects were not observed, suggesting that the storage temperature influences trolox action [63].

Vitamin C, also known as ascorbic acid, is a water-soluble vitamin associated with the preservation of the sperm cells genetic integrity by inhibiting oxidative damages to sperm DNA [52]. An improvement in the viability and motility of Awassi ram sperm stored at $5^{\circ} \mathrm{C}$ was reported with the inclusion of vitamin $\mathrm{C}$ $(0.9 \mathrm{mg} / \mathrm{mL})$ in a Tris-based extender [75]. Concurrently, it has been reported that cooled ram semen treated with vitamin $\mathrm{C}(4.5 \mathrm{mg} / \mathrm{mL})$ up to $72 \mathrm{~h}$ negatively influenced sperm parameters except for acrosome integrity [78], suggesting that lower concentrations of vitamin $\mathrm{C}$ are more efficient than greater ones.

Another water-soluble vitamin is vitamin $B_{12}$ which functions as a coenzyme in several biochemical reactions, such as methionine synthesis and the metabolism of branched amino acids [79]. Sperm kinematics, viability and membrane integrity were improved with vitamin $B_{12}$ supplementation $(2 \mathrm{mg} / \mathrm{mL})$ in a Tris-based extender for crossbred and Dallagh rams conserved in liquid form [80]. In the same vein, it has been reported that using the same dose of vitamin $B_{12}$ as a supplement reduced pre-freezing damages of ram spermatozoa [81].

\subsubsection{Amino Acids and Proteins}

Amino acids are non-enzymatic scavengers with some antioxidant properties and are present in seminal plasma in large amount [71]. Supplementation of extenders with amino acids (e.g. cysteine, cysteamine, dithioerythritol, methionine, and taurine) had a positive effect on sperm parameters [49] [54] [78] [82] [83].

Cysteine is a low molecular weight amino acid containing thiols that is involved in glutathione biosynthesis. Cysteine prevents sperm damages due to toxic oxygen metabolites induced by LPO [84]. Inclusion of cysteine (1 mM) to semen extender preserved progressive motility, morphology and reduced LPO but did not affect viability during chilled storage at $5^{\circ} \mathrm{C}$ up to $96 \mathrm{~h}$ [73]. Greater concentrations of cysteine ( 2 and $4 \mathrm{mM}$ ) improved motility, viability, and acrosome integrity of ram semen during liquid storage using a Tris-based extender [49].

Cysteamine illustrates its antioxidant and antiapoptotic properties by inducing intralysosomal cysteine accumulation [85]. The majority of the studies regarding extender supplementation with cysteamine to preserve ram semen has been done for cryopreservation [86] [87] [88]. However, when using cysteamine $(1 \mathrm{mM})$ as an additive to extender during liquid storage up to $72 \mathrm{~h}$, it has been reported an increase in motility and total glutathione levels, and a decrease in LPO [54].

Showing a similar property as dithiothreitol, an antioxidant known as a protamine disulfide bond reducing agent [89], dithioerythritol has been assessed for 
its potential to improve liquid storage of ram sperm at $5^{\circ} \mathrm{C}$ up to $72 \mathrm{~h}$. While no significant effect was recorded on sperm motility and LPO following dithioerythritol treatment $(0.5,1,2 \mathrm{mM})$, GPx and GSH activities significantly increased with the highest dithioerythritol concentration [82].

Another amino acid that has been used to reduce damages to sperm during storage is methionine. Methionine acts as a precursor amino acid for glutathione in the protection of cells against oxidative damages and plays a vital role in detoxification [90]. It has been demonstrated that methionine (1, 2 and $4 \mathrm{mM})$ improved sperm motility, viability and mitochondrial activity of ram sperm during liquid storage [82] [83].

The beneficial effects of taurine as an antioxidant in biological systems have been attributed to its ability to stabilize bio-membranes [91], to scavenge ROS [92] and to reduce the production of LPO end-products [93]. Taurine (50 mM) provided a significant improvement in sperm survival during $6 \mathrm{~h}$ of liquid storage at $5^{\circ} \mathrm{C}$ [15]. Using a lower concentration of taurine $(25 \mathrm{mM})$, it was reported an enhancement of sperm motility and a decrease of sperm abnormalities following $72 \mathrm{~h}$ preservation at $4^{\circ} \mathrm{C}[78]$.

Regarding proteins, bovine serum albumin (BSA) protects the membrane integrity of sperm cells against heat [94]. Using BSA (1\% and 3\%) alone or in combination with sucrose (10\%) as additives to ram semen extender, it was reported low or no effect on sperm motility and membrane integrity up to $48 \mathrm{~h}$ storage at $5^{\circ} \mathrm{C}[74]$.

Kinetin is part of class 6-aminopurines that is adenine carrying a furan-2-ylmethyl substituent at the exocyclic amino group. The antioxidative properties of kinetin have been described [95]. Kinetin has been tested as an additive to ram semen extender during chilled storage up to $72 \mathrm{~h}$. It was concluded that kinetin at appropriate concentrations $(25-100 \mu \mathrm{M})$ improves spermatozoa kinematics, viability, sperm plasma membrane functionality and antioxidative parameters [48].

\subsubsection{Plant Extracts}

Recently, there has been a growing interest in natural antioxidant present in fruits, vegetables, plants, oil seeds, and herbs to preserve semen quality. Their phytochemical composition and current use in the cosmetic, pharmaceutics and food industry with beneficial effects make them a promising track. Due to their strong antioxidant potential and abundance in biochemical compounds, several studies have scrutinized the potential of plant extracts to limit or prevent storage-associated damages to sperm (Table 3 ).

Among these plants, Alnus incana which is abundant in diarylheptanoids (curcumin and oregonin) and phenolic compounds, which have antioxidant properties, has benefited a special interest. Oregonin extracted from Alnus incana bark improved sperm motility and mitochondria status during liquid storage of ram semen at $5^{\circ} \mathrm{C}$ up to $48 \mathrm{~h}$. Besides, fertility tests assessed by cervical AI revealed a greater pregnancy rate for oregonin-treated spermatozoa in comparison to control (80\% versus $60 \%)$ [13]. 
Table 3. Summary of noteworthy results of liquid preserved ram sperm quality obtained with the addition of plant derivatives in extenders.

\begin{tabular}{lllc}
\hline Plant's additives & Extenders & \multicolumn{1}{c}{ Improved parameters } & References \\
\hline Oregonin & TGGY & Motility, mitochondria status & {$[13]$} \\
Cactus seed oil & SM & $\begin{array}{l}\text { Motility, viability LPO and DNA } \\
\text { fragmentation }\end{array}$ & {$[96]$} \\
Acetone extract of & TEY & Motility, viability, membrane integrity, & \\
Opuntia ficus indica & TEY & abnormality, DNA fragmentation, and LPO & {$[12]$} \\
Lycopene & TFEY & $\begin{array}{l}\text { mitochondrial activity, motility, and total } \\
\text { glutathione }\end{array}$ & {$[54]$} \\
Silymarin & TG & $\begin{array}{l}\text { Motility, acrosome integrity, membrane } \\
\text { integrity, and LPO }\end{array}$ & {$[97]$} \\
& & Viability, progressive motility, membrane & \\
Argan oil & SM & integrity spontaneous and induced LPO and & {$[42]$} \\
& TEY & DNA fragmentation & \\
\hline
\end{tabular}

Oregonin: Secondary metabolite extracted from Alnus incana bark; Lycopene: Carotenoid found in red fruits; Sylimarin: Polyphenolic flavonoid antioxidant isolated from milk thistle (Silybum marianum (L.)); TGGY: Tris-glucose-glycerol-egg yolk; SM: Skim milk; TG: Tris-glucose; TEY: Tris-egg yolk; LPO: TFEY: Tris-fructose-egg yolk; Lipid peroxidation; Maximum storage duration: $48-72 \mathrm{~h}$; Storage temperature: $5^{\circ} \mathrm{C}$ or $15^{\circ} \mathrm{C}$.

Hydroxytyrosol (HT) and 3,4-dihydroxyphenylglycol (DHPG) are both olive oil waste-derived phenolic components with strong antioxidant potential [98] [99]. The use of HT, DHPG and the combination of both antioxidants as additives in ram semen extenders at $5^{\circ} \mathrm{C}$ and $15^{\circ} \mathrm{C}$ up to $96 \mathrm{~h}$ showed slight impact on the sperm motility but did not show any effects on fertility as assessed by vaginal AI [62].

Another plant that the extract has been used in semen storage is Cladode (Opuntia ficus-indica). This plant is rich in different antioxidant compounds including tocopherols, polyphenols, flavonoids, tannins, carbohydrates, phenolic acids, minerals and sulfur amino acids [100] and possesses a considerable antioxidant activity [99]. The results of a study indicated that the inclusion of the acetone extract of Opuntia ficus-indica ( $1 \% \mathrm{v} / \mathrm{v})$ in the skim milk and Tris-egg yolk extenders increased the sperm motility, viability, membrane integrity, and decreased the abnormalities, LPO, and DNA fragmentation during liquid storage up to $72 \mathrm{~h}$ compared to control group [12]. Similar results were recorded with the addition of argan oil and cactus seed oil in small amounts to Tris-egg yolk/skim milk extender [42] [96].

Another compound that has been used to supplement extender is lycopene. Lycopene is the most plentiful carotenoid in red fruits like tomatoes and it is considered to be the prime antioxidant singlet oxygen quencher of all carotenoids [101]. Lycopene (0.5 and $2 \mathrm{mM}$ ) can be added to Tris-based extender to improve the ram sperm motility, viability, mitochondrial activity and oxidative stress parameters during liquid storage at $5^{\circ} \mathrm{C}$ [54].

Silymarin is a polyphenolic flavonoid antioxidant isolated from milk thistle 
(Silybum marianum (L.)) [102]. Silymarin is an efficient antioxidant, scavenging free radicals and protecting cells against LPO [103]. It has been reported that the addition of sylimarin $(100 \mu \mathrm{g} / \mathrm{L})$ to a Tris-glucose extender improves motility, membrane and acrosome integrity, and reduces LPO as indicated by the MDA concentration during liquid storage of ram semen at $5^{\circ} \mathrm{C}$ up to $72 \mathrm{~h}$ [97].

Caffeine (1,3,7-trimethylxanthine) is a natural stimulant belonging to the methylxanthine class and has been utilized as a supplement in sperm capacitation medium to enhance progressive motility in IVF schemes. Inclusion of different levels (0.1-0.4 mM) of caffeine to Tris-glucose-egg yolk extender during liquid storage of ram semen up to $48 \mathrm{~h}$ revealed that low $(0.1 \mathrm{mM})$ and medium $(0.2$ $\mathrm{mM}$ ) concentrations of caffeine have a positive impact on physical characteristics and enzymatic activity of ram sperm than higher concentrations [39]. Contrariwise, another study reported no effect of $0.1 \mathrm{mM}$ caffeine supplementation in Tris-citric acid extender on progressive motility after $48 \mathrm{~h}$ of liquid storage [38]. Furthermore, using $4 \mathrm{mM}$ caffeine, it was reported an enhancement of refrigerated sperm motility and a reduction of apoptosis, hence underlining the controversy about caffeine concentration [104].

Several studies have revealed the antioxidative properties of resveratrol (3,5,4-trihydroxystilbene, polyphenol found in some fruits like grapes) and its ability to reduce mitochondrial ROS production, scavenge superoxide radicals, decrease apoptosis, and inhibit lipid peroxidation as well as regulate the expression of antioxidant cofactors and enzymes [105] [106]. In a recent study, resveratrol supplementation $(200,400 \mathrm{mM})$ to Tryladyl ${ }^{\circledR}$ extender have shown to protect and maintain ram sperm head morphology and enhance some motion characteristics during chilled storage at $5^{\circ} \mathrm{C}$ up to 7 days likely via its antioxidant potential as indicated by MDA, SOD, and GSH indexes [107]. Moreover, the IVF test revealed that the highest cleavage and blastocyst rates were achieved with spermatozoa treated with $400 \mathrm{mM}$ resveratrol at $5^{\circ} \mathrm{C}$ for $72 \mathrm{~h}$.

\subsubsection{Other Compounds}

It is noteworthy that there is a wide range of other compounds with established potential to reduce the storage-associated damages to sperm.

Gelatin is a natural water-soluble compound that can increase extender's viscosity. The addition of gelatin to a standard milk extender during storage of ram spermatozoa at $15^{\circ} \mathrm{C}$ for up to 2 days, led to improved survival and in vitro penetrating ability over the use of the normal liquid extender [108]. Moreover, it has been demonstrated that the inclusion of gelatin in the cooling extender promotes the maintenance of sperm motility and acrosome integrity [37]. Gelatin may avoid cell sedimentation, and consequently reduce changes in medium conditions or composition; immobilize spermatozoa, reducing the metabolic demands of motion, while preserving their fertilization potential [109]. However, the addition of gelatin to the semen extender for 12/24 h storage did not lead to improved fertility results following vaginal insemination [110].

Royal jelly-which is produced by the hypo-pharyngeal and mandibular 
glands of worker honeybees-is primarily composed of water $(60 \%-70 \%)$, protein $(12 \%-15 \%)$, sugars, lipids, vitamins, salt, and free amino acids (10\% - 16\%). The royal jelly supplementation at lower concentrations $(0.5 \%$ and $1 \%)$ has been shown to improve the ram sperm kinematics and plasma membrane functionality during liquid storage at $4^{\circ} \mathrm{C}$, likely thanks to its antioxidative/antinitrosative capacities. However at higher concentration (2\%), royal jelly failed to preserved sperm parameters and the authors hypothesized that natural substances with antioxidant effects may act as double-edged swords, meaning that the high concentration of exogenous antioxidants may disrupt redox balance [57].

Melatonin (N-acetyl-5-methoxytryptamine) is a substance secreted by the pineal gland of all mammalian species with a wide range of properties among which antioxidant activity [45]. Inclusion of melatonin $(0.1,1,3 \mathrm{mM})$ in a Tris-based extender during storage of ram semen at $5^{\circ} \mathrm{C}$ up to $48 \mathrm{~h}$ improved sperm motility parameters except for head displacement and sperm track straightness [111]. A more detailed study, reported beneficial effects of inclusion of melatonin $(0.05-0.4 \mathrm{mM})$ in motility, plasma membrane integrity, mitochondrial activity and total antioxidant activity during a 5-days cooled storage of ram semen at $4^{\circ} \mathrm{C}, 0.1 \mathrm{mM}$ melatonin being the optimal concentration [112].

A synthetic analogue of coenzyme Q10, idebenone (2-(10-hydroxydecyl)-5,6dimethoxy-3-methyl-cyclohexa-2,5-diene-1,4-dione) has been reported as a potent antioxidant [113]. Idebenone has been shown to be an efficient antioxidant additive during $72 \mathrm{~h}$ storage at $4^{\circ} \mathrm{C}$, improving cell membrane functionality and viability by ameliorating nitrosative and peroxidative stress [114].

Tempol (4-hydroxy-2,2,6,6-tetramethylpiperidine-1-oxyl) and Mito-Tempo ((2-(2,2,6,6-Tetramethylpiperidin-1-oxyl-4-ylamino)-2-oxoethyl)triphenylphosp honium chloride) are both antioxidant compounds with SOD-like activity which have been used as additives to extenders to reduce storage-associated damages to sperm cells and maintain fertility [5] [35]. Ram semen diluted with media containing Tempol and stored at $17^{\circ} \mathrm{C}$ or $22^{\circ} \mathrm{C}$ up to $72 \mathrm{~h}$ demonstrated increased motility. Moreover, in vitro tests revealed that Tempol-treated spermatozoa show better fertilization and blastocyst rates in comparison to control [5]. More recently, using 5 and $50 \mu \mathrm{M}$ of Mito-Tempo as a supplement to cooling medium has shown to improve sperm total motility, progressive motility, membrane functionality, viability and lower MDA concentration during 24 and 48 h storage. Also, pregnancy, parturition and lambing rates have shown to be higher when ewes were inseminated with $24 \mathrm{~h}$-chilled semen samples treated with $\mathrm{Mi}$ to-TEMPO (5 and $50 \mu \mathrm{M}$ ) compared to the control group [35].

\subsection{Supplementation of Extenders with Seminal Plasma}

The seminal plasma (SP) consists of proteins, enzymatic and non-enzymatic antioxidants that improve the protection of sperm from oxidative stress and prevent capacitation of ram sperm [115]. The SP, collected from the same or different animal species has been scrutinized in liquid or frozen extenders for its 
potential to reduce the damaging effects associated with lower temperatures and cryodamage of mammalian sperm [116]. However, homologous SP appears to be more favorable for ram compared to bull spermatozoa even during long exposure times [117]. The decline of fertility following cervical insemination with liquid preserved ram sperm can be ascribed to the loss of SP referred to as the "dilution effect" [117]. Accordingly, supplementation of a simple saline medium with $10 \%-25 \%$ SP reduced the loss of viability of sperm diluted to $10 \times 10^{6} / \mathrm{mL}$ when incubated for $12 \mathrm{~h}$ at $37^{\circ} \mathrm{C}$ [14]. Moreover, a higher pregnancy rate was recorded following the addition of $30 \% \mathrm{SP}$ during storage at $5^{\circ} \mathrm{C}$ for $24 \mathrm{~h}$ in a Tris-egg yolk extender compared to SP-free (48.7\% versus $31.1 \%)$ [65]. SP at $20 \%$ and $40 \%$ concentrations has a protective effect on ram sperm motility after $24 \mathrm{~h}$ of liquid storage [118].

\subsection{Supplementation of Extenders with Sugars}

Carbohydrates in their different forms (monosaccharides, disaccharides, and trisaccharides) have been extensively considered in semen storage. Sugars serve as a source of energy for spermatozoa during incubation [119] and maintain the osmotic balance of extenders [120]. Previous studies have elucidated the effect of increasing the osmolality of a basic Tris extender with sucrose, trehalose or raffinose on ram sperm parameters and fertility rates after cervical insemination with preserved sperm. The study concluded that a range of sugar concentration of $50-100 \mathrm{mM}$ is beneficial for sperm quality and that with the inclusion of trehalose or raffinose at $100 \mathrm{mM}$, the fertility rate is nearly triple of the control [121].

Trehalose is a non-permeant, non-reducer disaccharide made of two molecules of glucose linked together by a relatively stable 1,1- $\alpha$-glycosidic bound. In addition to its role as an energy source, it has a protective action related both to osmotic effect and specific interactions with membrane phospholipids, rendering hypertonic media, causing cellular osmotic dehydration before freezing, and then decreasing the amount of cell injury by ice crystallization [122]. Trehalose has been used in several experiments to prevent or reduce storage-associated damages. It has been demonstrated that $50 \mathrm{mM}$ trehalose is suitable for preserving the motility, viability and sperm membrane integrity of ram semen following a $30 \mathrm{~h}$ chilled storage at $5^{\circ} \mathrm{C}$ [15]. Similarly, it has been reported that adding trehalose (10 and $25 \mathrm{mM}$ ) to a Tris-based extender improves ram sperm motility, viability, and mitochondrial activity during liquid storage at $5^{\circ} \mathrm{C}$ for up to $96 \mathrm{~h}$ [49].

Sucrose is a disaccharide, non-permeable cryoprotectant commonly used in sperm storage, which the properties are ascribed to its ability to maintain osmotic pressure of the diluent and sperm membrane integrity [1]. Comparing different extenders at preserving ram sperm quality and antioxidant profile during semen storage at $15^{\circ} \mathrm{C}$ up to $6 \mathrm{~h}$, it was reported that sucrose base extender was less effective in comparison to milk-egg yolk extender [123]. Moreover, sucrose at different concentrations $(0.4-0.8 \mathrm{M})$ reduced pre-freezing sperm quali- 
ty for samples preserved at $5^{\circ} \mathrm{C}$ and $15^{\circ} \mathrm{C}$, while positive effects were recorded for total motility, viability and membrane functionality following freeze-thawing [124].

Raffinose is a trisaccharide that plays a cryoprotective role by decreasing intracellular ice crystal formation through its interaction with membrane lipids and proteins during cryopreservation [125]. The use of raffinose in combination with lactose and sucrose as additives improved motility after $48 \mathrm{~h}$ ram semen storage at $4^{\circ} \mathrm{C}$ and pregnancy rate following cervical insemination [3].

\subsection{Supplementation of Extenders with Fatty Acids}

The ram sperm has a greater polyunsaturated/saturated fatty acid ratio than other species [23]. This ratio determines the sensitivity of sperm to cold shock [126]. The high content of PUFAs within the plasma membrane is assumed to impart greater fluidity and lesser resistance to cold shock due to the presence of many double bonds [127].

A study concluded that supplementation of a Tris-egg yolk-based extender with palmitoleic acid promoted kinematics, microscopic and antioxidative parameters of ram spermatozoa during liquid storage at $4^{\circ} \mathrm{C}$ up to $72 \mathrm{~h}$ [25]. Also, it was reported that oleic acid supplementation increased the viability, plasma membrane integrity, total antioxidant capacity and SOD and decreased the amounts of MDA and nitric oxide during liquid storage of ram sperm [128]. More recently, studies confirmed the beneficial effects of Omega 3 fatty acids inclusion in Tris-citric acid-egg yolk extender following liquid storage of ram semen [129]. These positive results were ascribed to the capacity of Omega 3 fatty acids to reduce the deleterious effects of oxidative stress and maintain the physical and kinematic properties of sperm cells. In the same vein, it has been reported that enrichment of egg yolk with PUFAs, particularly flaxseed oil or fish oil can preserve the quality of ram semen during liquid storage to a level whereby it can still be used with success in cervical transfers [35].

\subsection{Supplementation of Extenders with Nanoparticles}

Nanoparticles (NPs) are particles that are synthesized in extremely small size, at the nanometer scale, with flexible fabrication and high surface-area ratio and can be made from a variety of materials including metals, polysaccharides, and proteins [130]. Recent advances in nanotechnology resulted in the development of several NP formulations with potent antioxidant, anti-inflammatory, and antimicrobial properties [131] [132] [133] with potential applications in reproduction either in vitro or in vivo [134]. It has been shown that supplementation of soybean lecithin extender with cerium oxide $\left(\mathrm{CeO}_{2}\right)$ NPs (an oxygen storing molecule) during ram semen storage at $4^{\circ} \mathrm{C}$ for $96 \mathrm{~h}$ improves sperm motility characteristics, and protects the integrity of plasma membrane [17]. However, ROS production was not affected regardless of co-incubation with NPs, suggesting that apart from scavenging and/or preventing excess ROS production, alternative mechanisms are involved in the protection of sperm cells against sto- 
rage-associated damages.

\section{Conclusion}

Ram semen storage remains a critical step as the quality of inseminated spermatozoa strongly determines the success of AI. Given their high content in PUFAs, ram spermatozoa are highly susceptible to oxidative stress which is amplified during storage following LPO. Supplementation of extenders with different compounds, especially plant extracts can improve sperm quality and fertility rates. However, multiplying on-field fertility tests and shedding light on the underlying mechanisms by which these beneficial effects occur will allow optimal use of these compounds as additives to extenders, thus better sperm quality and fertility rates.

\section{Acknowledgements}

The present work has received support from the International Foundation for Science, grant $\mathrm{N}^{\circ} \mathrm{I}-3-\mathrm{B}-6120-1$.

\section{Conflicts of Interest}

The authors declare no conflicts of interest regarding the publication of this paper.

\section{References}

[1] Salamon, S. and Maxwell, W.M.C. (2000) Storage of Ram Semen. Animal Reproduction Science, 62, 77-111. https://doi.org/10.1016/S0378-4320(00)00155-X

[2] Maxwell, W.M.C. and Salamon, S. (1993) Liquid Storage of Ram Semen: A Review. Reproduction, Fertility, and Development, 5, 613-638. https://doi.org/10.1071/RD9930613

[3] Stefanov, R.G., Anev, G. and Abadjieva, D.V (2015) Effect of Different Extenders and Storage Periods on Motility and Fertility of Ram Sperm. Macedonian Veterinary Review, 38, 85-89. https://doi.org/10.14432/j.macvetrev.2014.12.036

[4] Maxwell, W.M.C. and Stojanov, T. (1996) Liquid Storage of Ram Semen in the Absence or Presence of Some Antioxidants. Reproduction, Fertility, and Development, 8, 1013-1020. https://doi.org/10.1071/RD9961013

[5] Mara, L., Accardo, C., Pilichi, S., Dattena, M., Chessa, F., Chessa, B., Branca, A. and Cappai, P. (2005) Benefits of Tempol on Ram Semen Motility and In Vitro Fertility: A Preliminary Study. Theriogenology, 63, 2243-2253. https://doi.org/10.1016/j.theriogenology.2004.10.005

[6] Del Maestro, R.F. (1980) An Approach to Free Radicals in Medicine and Biology. ActaPhysiologicaScandinavica:Supplementum, 492, 153-168.

[7] Ikeda, M., Kodama, H., Fukuda, J., Shimizu, Y., Murata, M., Kumagai, J. and Tanaka, T. (1999) Role of Radical Oxygen Species in Rat Testicular Germ Cell Apoptosis Induced by Heat Stress. Biology of Reproduction, 61, 393-399. https://doi.org/10.1095/biolreprod61.2.393

[8] Zini, A., De Lamirande, E. and Gagnon, C. (1995) Low Levels of Nitric Oxide Promote Sperm Capacitation In Vitro. Journal of Andrology, 6, 424-431. 
[9] De Lamirande, E., Jiang, H., Zini, A., Kodama, H. and Gagnon, C. (1997) Reactive Oxygen Species and Sperm Physiology. Reviews of Reproduction, 2, 48-54.

[10] Bansal, A.K. and Bilaspuri, G.S. (2011) Impacts of Oxidative Stress and Antioxidants on Semen Functions. Veterinary Medicine International, 2011, Article ID: 686137. https://doi.org/10.4061/2011/686137

[11] Gundogan, M., Yeni, D., Avdatek, F. and Fidan, A.F. (2010) Influence of Sperm Concentration on the Motility, Morphology, Membrane and DNA Integrity along with Oxidative Stress Parameters of Ram Sperm during Liquid Storage. Animal Reproduction Science, 122, 200-207. https://doi.org/10.1016/j.anireprosci.2010.08.012

[12] Allai, L., Druart, X., Öztürk, M., BenMoula, A., Nasser, B. and El Amiri, B. (2016) Protective Effects of Opuntia ficus-indica Extract on Ram Sperm Quality, Lipid Peroxidation and DNA Fragmentation during Liquid Storage. Animal Reproduction Science, 175, 1-9. https://doi.org/10.1016/j.anireprosci.2016.09.013

[13] Abadjieva, D., Yotov, S., Mladenova, V., Lauberte, L. and Kalvanov, I. (2020) Positive Effect of Natural Antioxidant Oregonin from Alnusincana Bark on Ram Semen Quality Stored at $5^{\circ} \mathrm{C}$ for $48 \mathrm{~h}$. Research in Veterinary Science, 131, 153-158. https://doi.org/10.1016/j.rvsc.2020.04.021

[14] Ashworth, P.J.C., Harrison, R.A.P., Miller, N.G.A., Plummer, J.M and Watson, P.F. (1994) Survival of Ram Spermatozoa: Protective Effect of Simple Constituents of Culture Media as Compared with Seminal Plasma. Reproduction, Fertility, and Development, 6, 173-180. https://doi.org/10.1071/RD9940173

[15] Bucak, M.N. and Tekin, N. (2007) Protective Effect of Taurine, Glutathione and Trehalose on the Liquid Storage of Ram Semen. Small Ruminant Research, 73, 103-108. https://doi.org/10.1016/j.smallrumres.2006.12.001

[16] Zarei, M., Rostami, B., Masoumi, R., Shara, M., Shahir, M.H., Stear, M. and Catt, S. (2018) Egg Yolk Enriched with Polyunsaturated Fatty Acids (PUFAs) Improves the Shelf Life of Ram Semen in Liquid Storage. Small Ruminant Research, 166, 87-92. https://doi.org/10.1016/j.smallrumres.2018.05.002

[17] Falchi, L., Galleri, G., Dore, G.M., Zedda, M.T., Pau, S., Bogliolo, L., Ariu, F., Pinna, A., Nieddu, S., Innocenzi, P. and Ledda, S. (2018) Effect of Exposure to $\mathrm{CeO}_{2} \mathrm{Na}-$ noparticles on Ram Spermatozoa during Storage at $4^{\circ} \mathrm{C}$ for 96 Hours. Reproductive Biology and Endocrinology, 16, Article No. 19. https://doi.org/10.1186/s12958-018-0339-9

[18] O’Hara, L., Hanrahan, J.P., Richardson, L., Donovan, A., Fair, S., Evans, A.C.O. and Lonergan, P. (2010) Effect of Storage Duration, Storage Temperature, and Diluent on the Viability and Fertility of Fresh Ram Sperm. Theriogenology, 73, 541-549. https://doi.org/10.1016/j.theriogenology.2009.10.009

[19] Falchi, L., Galleri, G., Zedda, M.T., Pau, S., Bogliolo, L., Ariu, F. and Ledda, S. (2018) Liquid Storage of Ram Semen for 96 h: Effects on Kinematic Parameters, Membranes and DNA Integrity, and ROS Production. Livestock Science, 207, 1-6. https://doi.org/10.1016/j.livsci.2017.11.001

[20] Agarwal, A. and Prabakaran, S.A. (2005) Mechanism, Measurement and Prevention of Oxidative Stress in Male Reproductive Physilogy. Indian Journal of Experimental Biology, 43, 963-974.

[21] Rahal, A., Kumar, A., Singh, V., Yadav, B., Tiwari, R., Chakraborty, S. and Dhama, K. (2014) Oxidative Stress, Prooxidants, and Antioxidants: The Interplay. BioMed Research International, 2014, Article ID: 761264. https://doi.org/10.1155/2014/761264

[22] Trachootham, D., Lu, W., Ogasawara, M.A., Rivera-del Valle, N. and Huang, P. 
(2008) Redox Regulation of Cell Survival. Antioxidant and Redox Signaling, 10, 1343-1373. https://doi.org/10.1089/ars.2007.1957

[23] Maxwell, W.M.C. and Watson, P.F. (1996) Recent Progress in the Preservation of Ram Semen. Animal Reproduction Science, 42, 55-65.

https://doi.org/10.1016/0378-4320(96)01544-8

[24] Yin, H., Xu, L. and Porter, N.A. (2011) Free Radical Lipid Peroxidation: Mechanisms and Analysis. Chemical Reviews, 111, 5944-5972. https://doi.org/10.1021/cr200084z

[25] Eslami, M., Ghasemiyan, H. and Hashem, E.Z. (2017) Semen Supplementation with Palmitoleic Acid Promotes Kinematics, Microscopic and Antioxidative Parameters of Ram Spermatozoa during Liquid Storage. Reproduction in Domestic Animals, 52, 49-59. https://doi.org/10.1111/rda.12802

[26] Buhr, M.M., Curtis, E.F. and Kakuda, N.S. (1994) Composition and Behavior of Head Membrance Lipids of Fresh and Cryopreserved Boar Semen. Cryobiology, 31, 224-238. https://doi.org/10.1006/cryo.1994.1028

[27] Watson, P.F. (2000) The Causes of Reduced Fertility with Cryopreserved Semen. Animal Reproduction, 60-61, 481-492. https://doi.org/10.1016/S0378-4320(00)00099-3

[28] Hamilton, T.R.D.S., De Castro, L.S., Delgado, J.D.C., De Assis, P.M., Siqueira, A.F.P., Mendes, C.M., Goissis, M.D., Muiño-Blanco, T., Cebrián-Pérez, J.Á., Nichi, M., Visintin, J.A. and D'AvilaAssumpcao, M.E.O. (2016) Induced Lipid Peroxidation in Ram Sperm: Semen Profile, DNA Fragmentation and Antioxidant Status. Reproduction, 151, 379-390. https://doi.org/10.1530/REP-15-0403

[29] Ayala, A., Muñoz, M.F. and Argüelles, S. (2014) Lipid Peroxidation: Production, Metabolism, and Signaling Mechanisms of Malondialdehyde and 4-Hydroxy-2-Nonenal. Oxidative Medicine and Cellular Longevity, 2014, Article ID: 360438. https://doi.org/10.1155/2014/360438

[30] Iqbal, N. and Hunter, A.G. (1995) Effect of Various Capacitation Systems on Bovine Sperm Motion Characteristics, Acrosome Integrity, and Induction of Hyperactivation. Journal of Dairy Science, 78, 91-102. https://doi.org/10.3168/jds.S0022-0302(95)76620-6

[31] De Lamirande, E., Leclerc, P. and Gagnon, C. (1997) Capacitation as a Regulatory Event that Primes Spermatozoa for the Acrosome Reaction and Fertilization. Molecular Human Reproduction, 3, 175-194. https://doi.org/10.1093/molehr/3.3.175

[32] Drobnis, E.Z., Crowe, L.M., Berger, T., Anchordoguy, T.J., Overstreet, J.W. and Crowe, J.H. (1993) Cold Shock Damage Is Due to Lipid Phase Transitions in Cell Membranes: A Demonstration Using Sperm as a Model. The Journal of Experimental Zoology, 265, 432-437. https://doi.org/10.1002/jez.1402650413

[33] Câmara, D.R., Mello-Pinto, M.M.C., Pinto, L.C., Brasil, O.O., Nunes, J.F. and Guerra, M.M.P. (2011) Effects of Reduced Glutathione and Catalase on the Kinematics and Membrane Functionality of Sperm during Liquid Storage of Ram Semen. Small Ruminant Research, 100, 44-49. https://doi.org/10.1016/j.smallrumres.2011.05.010

[34] Paul, R.K., Kumar, D. and Naqvi, S.M.K. (2017) Antioxidants Protect Proteins' Anchorage to the Bilayer by Improving Plasma Membrane Integrity of Ram Spermatozoa during Liquid Preservation in a Soya Lecithin-Based Diluent. Reproduction in Domestic Animals, 52, 1052-1060. https://doi.org/10.1111/rda.13023

[35] Zarei, F., Kia, H.D., Masoudi, R., Moghaddam, G. and Ebrahimi, M. (2021) Supplementation of Ram's Semen Extender with Mito-TEMPO I: Improvement in 
Quality Parameters and Reproductive Performance of Cooled-Stored Semen. Cryobiology, 98, 15-218. https://doi.org/10.1016/j.cryobiol.2020.10.018

[36] Shi, L., Jin, T., Hu, Y., Ma, Z., Niu, H. and Ren, Y. (2020) Effects of Reduced Glutathione on Ram Sperm Parameters, Antioxidant Status, Mitochondrial Activity and the Abundance of Hexose Transporters during Liquid Storage at $5^{\circ}$ C. Small Ruminant Research, 189, Article ID: 106139.

https://doi.org/10.1016/j.smallrumres.2020.106139

[37] Gheller, M.S.M., Corcini, C.D., Pradieé, J., Rizzoto, G., Junior, T.L., Moreira, F. and Junior, A.S.V. (2018) Gelatin Protects Ram Semen Stored for $72 \mathrm{~h}$ at $5^{\circ}$ C. Small Ruminant. Research, 158, 54-56. https://doi.org/10.1016/j.smallrumres.2017.09.011

[38] Rateb, S.A., Khalifa, M.A., El-hamid, I.S.A. and Shedeed, H.A. (2020) Enhancing Liquid-Chilled Storage and Cryopreservation Capacities of Ram Spermatozoa by Supplementing the Diluent with Different Additives. Asian-Australasian Journal of Animal Sciences, 33, 1068-1076. https://doi.org/10.5713/ajas.19.0338

[39] El-Hamid, I.S.A. (2019) Effect of Adding Different Levels of Caffeine in the Extender on Some Biochemical Constituents, Enzymatic Activities and Physical Characteristics of Chilled and Frozen Ram Semen. Reproduction in Domestic Animals, 54, 225-233. https://doi.org/10.1111/rda.13339

[40] Peris-Frau, P., Soler, A.J., Iniesta-Cuerda, M., Martín-Maestro, A., Sánchez-Ajofrín, I., Medina-Chávez, D.A., Fernández-Santos, M.R., García-Álvarez, O., Maroto-Morales, A., Montoro, V. and Garde, J.J. (2020) Sperm Cryodamage in Ruminants: Understanding the Molecular Changes Induced by the Cryopreservation Process to Optimize Sperm Quality. International Journal of Molecular Sciences, 21, 2781. https://doi.org/10.3390/ijms21082781

[41] Kasimanickam, R., Kasimanickam, V., Tibary, A. and Pelzer, K. (2011) Effect of Semen Extenders on Sperm Parameters of Ram semen during Liquid Storage at $4^{\circ} \mathrm{C}$. Small Ruminant Research, 99, 208-213. https://doi.org/10.1016/j.smallrumres.2011.03.057

[42] Allai, L., Druart, X., Contell, J., Louanjli, N., Moula, A.B., Badi, A., Essamadi, A., Nasser, B. and El Amiri, B. (2015) Effect of Argan Oil on Liquid Storage of Ram Semen in Tris or Skim Milk Based Extenders. Animal Reproduction Science, 160, 57-67. https://doi.org/10.1016/j.anireprosci.2015.07.003

[43] Arando, A., Delgado, J.V., León, J.M., Nogales, S., Navas-González, F.J., Pizarro, M.G. and Pérez-Marín, C.C. (2019) Effect of Three Commercial Extenders on Sperm Motility and Fertility in Liquid Ram Semen Stored at $15^{\circ} \mathrm{C}$ or $5^{\circ} \mathrm{C}$. ActaVeterinariaHungarica, 67, 430-444. https://doi.org/10.1556/004.2019.043

[44] Halliwell, B. and Gutteridge, J.M.C. (1999) Free Radicals in Biology and Medicine. 3rd Edition, Oxford University Press, Oxford.

[45] Jang, H.Y., Kim, Y.H., Kim, B.W., Park, I.C., Cheong, H.T., Kim, J.T., Park, C.K., Kong, H.S., Lee, H.K. and Yang, B.K. (2010) Ameliorative Effects of Melatonin against Hydrogen Peroxide-Induced Oxidative Stress on Boar Sperm Characteristics and Subsequent In Vitro Embryo Development. Reproduction in Domestic Animals, 45, 943-950. https://doi.org/10.1111/j.1439-0531.2009.01466.x

[46] Rekha, A., Zohara, B.F., Bari, F.Y. and Alam, M.G.S. (2016) Comparisons of Commercial Triladyl and Locally Manufactured Extenders for the Chilling of Semen and their Effects on Pregnancy Rates after Transcervical AI in Bangladeshi Indigenous (Ovis aries) Sheep. Animal Reproduction, 13, 735-742. https://doi.org/10.21451/1984-3143-AR733

[47] Bucak, M.N., Bodu, M., Başpinar, N., Güngör, Ş., Ili, P., Acibaeva, B., Topraggaleh, 
T.R. and Dursun, Ş. (2019) Influence of Ellagic Acid and Ebselen on Sperm and Oxidative Stress Parameters during Liquid Preservation of Ram Semen. Cell Journal, 21, 7-13.

[48] Hashem, E.Z. and Eslami, M. (2016) Kinetin Improves Motility, Viability and Antioxidative Parameters of Ram Semen during Storage at Refrigerator Temperature. Cell Tissue Bank, 19, 97-111. https://doi.org/10.1007/s10561-016-9604-3

[49] Gungor, S., Ozturk, C. and Omur, A.D. (2017) Positive Effects of Trehalose and Cysteine on Ram Sperm Parameters. Veterinarni Medicina, 62, 245-252. https://doi.org/10.17221/131/2016-VETMED

[50] Kasimanickam, R., Kasimanickam, V., Pelzer, K.D. and Dascanio, J.J. (2007) Effect of Breed and Sperm Concentration on the Changes in Structural, Functional and Motility Parameters of Ram-Lamb Spermatozoa during Storage at $4^{\circ} \mathrm{C}$. Animal Reproduction Science, 101, 60-73. https://doi.org/10.1016/j.anireprosci.2006.09.001

[51] Alçay, S., Toker, B., Üstüner, B., Nur, Z., Sagirkaya, H. and Soylu, K.M. (2014) Investigation of Relationships between DNA Integrity and Fresh Semen Parameters in Rams. Kafkas Universitesi Veteriner Fakultesi Dergisi, 20, 793-798.

[52] Fraga, C.G., Motchnik, P.A., Shigenaga, M.K., Helbock, H.J., Jacob, R.A. and Ames, B.N. (1991) Ascorbic Acid Protects against Endogenous Oxidative DNA Damage in Human Sperm. Proceedings of the National Academy of Sciences of the United States of America, 88, 11003-11006. https://doi.org/10.1073/pnas.88.24.11003

[53] Menvielle-Bourg, F.J. (2005) Superoxide Dismutase (SOD), a Powerful Antioxidant, Is Now Available Orally. Phytotherapie, 3, 118-121.

https://doi.org/10.1007/s10298-005-0087-9

[54] Akalin, P.P., Bucak, M.N., Güngör, Ş., Başpinar, N.,Çoyan, K., Dursun, Ş., Ili, P., Aksoy, A., Karaşör, Ö.F., Sariözkan, S. and Yeni, D. (2016) Influence of Lycopene and Cysteamine on Sperm and Oxidative Stress Parameters during Liquid Storage of Ram Semen at $5^{\circ}$ C. Small Ruminant Research, 137, 117-123. https://doi.org/10.1016/j.smallrumres.2016.03.017

[55] Lone, S.A., Prasad, J.K., Ghosh, S.K., Das, G.K., Balamurugan, B. and Verma, M.R. (2018) Study on Correlation of Sperm Quality Parameters with Antioxidant and Oxidant Status of Buffalo Bull Semen during Various Stages of Cryopreservation. Andrologia, 50, e12970.https://doi.org/10.1111/and.12970

[56] Aitken, R.J. (1995) Free Radicals, Lipid Peroxidation and Sperm Function. Reproduction, Fertility, and Development, 7, 659-668. https://doi.org/10.1071/RD9950659

[57] Moradi, A.R., Malekinejad, H., Farrokhi-Ardabili, F. and Bernousi, I. (2013) Royal Jelly Improves the Sperm Parameters of Ram Semen during Liquid Storage and Serves as an Antioxidant Source. Small Ruminant Research, 113, 346-352. https://doi.org/10.1016/j.smallrumres.2013.03.003

[58] Aitken, R.J., Buckingham, D. and Harkiss, D. (1992) Use of a Xanthine Oxidase Free Radical Generating System to Investigate the Cytotoxic Effects of Reactive Oxygen Species on Human Spermatozoa. Journal of Reproduction and Fertility,97, 441-450. https://doi.org/10.1530/jrf.0.0970441

[59] Maia, S., Dimas, S., Cecilia, C., Rdello, L., Cristina, I. and Gallego, S. (2010) Lipid Peroxidation and Generation of Hydrogen Peroxide in Frozen-Thawed Ram Semen Cryopreserved in Extenders with Antioxidants. Animal Reproduction Science, 122, 118-123. https://doi.org/10.1016/j.anireprosci.2010.08.004

[60] Gargari, B.P., Dehghan, P., Aliasgharzadeh, A. and Jafar-Abadi, M.A. (2013) Effects of High Performance Inulin Supplementation on Glycemic Control and Antioxidant Status in Women with Type 2 Diabetes. Diabetes and Metabolism Journal, 37, 
140-148. https://doi.org/10.4093/dmj.2013.37.2.140

[61] Aitken, R.J., Jones, K.T. and Robertson, S.A. (2012) Reactive Oxygen Species and Sperm Function-In Sickness and in Health. Journal of Andrology, 33, 1096-1106. https://doi.org/10.2164/jandrol.112.016535

[62] Arando, A., Delgado, V.J., Bermúdez-Oria, A., León, J.M., Fernández-Prior, Á., Nogales, S. and Pérez-Marín, C.C. (2020) Effect of Olive-Derived Antioxidants on Sperm Motility and Fertility in Liquid Ram Sperm stored at $15^{\circ} \mathrm{C}$ or $5^{\circ} \mathrm{C}$. Reproduction in Domestic Animals, 55, 325-332. https://doi.org/10.1111/rda.13631

[63] Mata-Campuzano, M., Álvarez-Rodríguez, M., Tamayo-Canul, J., López-Urueña, E., De Paz, P., Anel, L., Martínez-Pastor, F. and Álvarez, M. (2014) Refrigerated Storage of Ram Sperm in Presence of Trolox and GSH Antioxidants: Effect of Temperature, Extender and Storage Time. Animal Reproduction Science, 151, 137-147. https://doi.org/10.1016/j.anireprosci.2014.10.006

[64] Kubovičová, E., Ríha, L., Makarevich, A.V, Apolen, D. and Pivko, J. (2010) Effect of Different Semen Extenders and Additives to Insemination Doses on Ewe's Pregnancy Rate. Slovak Journal of Animal Science, 43, 118-122.

[65] López-Pérez, A. and Pérez-Clariget, R. (2012) Ram Seminal Plasma Improves Pregnancy Rates in Ewes Cervically Inseminated with Ram Semen Stored at $5^{\circ} \mathrm{C}$ for 24 hours. Theriogenology, 77, 395-399. https://doi.org/10.1016/j.theriogenology.2011.08.013

[66] Barreiros, A.L.B.S., David, J.M. and David, J.P. (2006) Oxidative Stress: Relations between the Formation of Reactive Species and the Organism's Defense. Química Nova, 29, 113-123. https://doi.org/10.1590/S0100-40422006000100021

[67] Kasimanickam, R., Pelzer, K.D., Kasimanickam, V., Swecker, W.S. and Thatcher, C.D. (2006) Association of Classical Semen Parameters, Sperm DNA Fragmentation Index, Lipid Peroxidation and Antioxidant Enzymatic Activity of Semenin Ram-Lambs. Theriogenology, 65, 1407-1421. https://doi.org/10.1016/j.theriogenology.2005.05.056

[68] Bucak, M.N., Ateşşahin, A. and Yüce, A. (2008) Effect of Anti-Oxidants and Oxidative Stress Parameters on Ram Semen after the Freeze-thawing Process. Small $R u$ minant Research, 75, 128-134. https://doi.org/10.1016/j.smallrumres.2007.09.002

[69] Sharafi, M., Forouzanfar, M., Hosseini, S.M., Hajian, M., Ostadhosseini, S., Hosseini, L., Abedi, P., Nili, N., Rahmani, H.R., Javaheri, A.R. and Esfahani, M.H.N. (2009) In Vitro Comparison of Soybean Lecithin Based-Extender with Commercially Available Extender for Ram Semen Cryopreservation. International Journal of Fertility and Sterility, 3, 149-152.

[70] Maia, M.D.S., Bicudo, S.D., Azevedo, H.C., Sicherle, C.C., Sousa, D.B.D. and Rodello, L. (2009) Motility and Viability of Ram Sperm Cryopreserved in a Tris-Egg yolk Extender Supplemented with Anti-Oxidants. Small Ruminant Research, 85, 85-90. https://doi.org/10.1016/j.smallrumres.2009.07.001

[71] Allai, L., Benmoula A., Maia, M.D.S, Nasser, B. and El Amiri, B. (2018) Supplementation of Ram Semen Extender to Improve Seminal Quality and Fertility Rate. Animal Reproduction Science, 192, 94-99. https://doi.org/10.1016/j.anireprosci.2018.03.019

[72] Amidi, F., Pazhohan, A., Nashtaei, M.S, Khodarahmian, M. and Nekoonam, S. (2016) The Role of Antioxidants in Sperm Freezing: A Review. Cell Tissue Banking, 17, 745-756.https://doi.org/10.1007/s10561-016-9566-5

[73] Zeitoun, M.M. and Al-Damegh, M.A. (2015) Effect of Nonenzymatic Antioxidants on Sperm Motility and Survival Relative to Free Radicals and Antioxidant Enzymes 
of Chilled-Stored Ram Semen. Open Journal of Animal Science, 5, 50-58. https://doi.org/10.4236/ojas.2015.51007

[74] Kheradmand, A., Babaei, H. and Abshenas, J. (2006) Comparative Evaluation of the Effect of Antioxidants on the Chilled-Stored Ram Semen. Iranian Journal of Veterinary Research, 7, 40-45.

[75] Azawi, O.I. and Hussein, E.K. (2013) Effect of Vitamins C or E Supplementation to Tris Diluent on the Semen Quality of Awassi Rams Preserved at $5^{\circ} \mathrm{C}$. Veterinary Research Forum, 4, 157-160.

[76] Pour, A.H., Tahmasbi, A.-M. andNaserain, A.-A. (2013) The Influence of Vitamin E on Semen Characteristics of Ghezel Rams in during Cooling and Frozen Process. European Journal of Zoological Research, 2, 94-99.

[77] Barclay, L.R.C., Artz, J.D. and Mowat, J.J. (1995) Partitioning and Antioxidant Action of the Water-Soluble Antioxidant, Trolox, between the Aqueous and Lipid Phases of Phosphatidylcholine Membranes: ${ }^{14} \mathrm{C}$ Tracer and Product Studies. Biochimica et Biophysica Acta, 1237, 77-85. https://doi.org/10.1016/0005-2736(95)00071-A

[78] Rather, H.A., Islam, R., Malik, A.A. and Lone, F.A. (2016) Addition of Antioxidants Improves Quality of Ram Spermatozoa during Preservation at $4^{\circ} \mathrm{C}$. Small Ruminant Research, 141, 24-28. https://doi.org/10.1016/j.smallrumres.2016.06.007

[79] Juanchi, X., Albarran, G. and Negron-Mendoza, A. (2000) Radiolysis of Cyanocobalamin (Vitamin B12). Radiation Physics and Chemistry, 57, 337-339. https://doi.org/10.1016/S0969-806X(99)00445-4

[80] Asadpour, R., Pourseif, M.M., Moghadam, G., Jafari, R., Tayefi, H. and Mahmodi, H. (2012) Effect of Vitamin B12 Addition to Extenders on Some Physicochemical Parameters of Semen in Crossbred Rams. African Journal of Biotechnology, 11, 11741-11745. https://doi.org/10.5897/AJB11.4060

[81] Hamedani, M.A., Tahmasbi, A.M. and Ahangari, Y.J. (2013) Effects of Vitamin B $B_{12}$ Supplementation on the Quality of Ovine Spermatozoa. Open Veterinary Journal, 3 , 140-144.

[82] Çoyan, K., Başpinaar, N., Bucak, M.N., Akalin, P.P., Ataman, M.B., Ömür, A.D., Güngör, Ş., Küçükgünay, S., Özkalp, B. and Sarı̈̈zkan, S. (2010) Influence of Methionine and Dithioerythritol on Sperm Motility, Lipid Peroxidation and Antioxidant Capacities during Liquid Storage of Ram Semen. Research in Veterinary Science, 89, 426-431. https://doi.org/10.1016/j.rvsc.2010.03.025

[83] Bucak, M.N., Çoyan, K., Öztürk, C., Güngör, Ş. and Ömür, A.D. (2012) Methionine Supplementation Improves Ram Sperm Parameters during Liquid Storage at $5^{\circ} \mathrm{C}$. Cryobiology, 65, 335-337. https://doi.org/10.1016/j.cryobiol.2012.09.002

[84] Meister, A. and Tate, S.S. (1976) Glutathione and Related Gamma-Glutamyl Compounds: Biosynthesis and Utilization. Annual Review of Biochemistry, 45, 559-604. https://doi.org/10.1146/annurev.bi.45.070176.003015

[85] Gahl, W.A., Bashan, N., Tietze, F., Bernardini, I. and. Schulman, J.D. (1982) Cystine Transport Is Defective in Isolated Leukocyte Lysosomes from Patients with Cystinosis. Science, 217, 1263-1265. https://doi.org/10.1126/science.7112129

[86] Bucak, M.N., Ateşşahin, A., Varışl1, Ö., Yüce, A., Tekin, N. and Akçay, A. (2007) The Influence of Trehalose, Taurine, Cysteamine and Hyaluronan on Ram Semen Microscopic and Oxidative Stress Parameters after Freeze-Thawing Process. Theriogenology, 67, 1060-1067. https://doi.org/10.1016/j.theriogenology.2006.12.004

[87] Cirit, Ü., Ba, H., Varıs, Ö., Clifford-Rathert, C. and Agca, Y. (2013) Comparison of 
Cryoprotective Effects of Iodixanol, Trehalose and Cysteamine on Ram Semen. Animal Reproduction Science, 139, 38-44. https://doi.org/10.1016/j.anireprosci.2013.03.010

[88] Najafi, A., Daghigh, H., Mohammadi, H., Hossein, M., Zanganeh, Z., Sharafi, M., Martinez-Pastor, F. and Adelust, H. (2014) Different Concentrations of Cysteamine and Ergothioneine Improve Microscopic and Oxidative Parameters in Ram Semen Frozen with a Soybean Lecithin Extender. Cryobiology, 69, 68-73. https://doi.org/10.1016/j.cryobiol.2014.05.004

[89] Watanabe, H. and Fukui, Y. (2006) Effects of Dithiothreitol and Boar on Pronuclear Formation and Embryonic Development Following Intracytoplasmic Sperm Injection in Pigs. Theriogenology, 65, 528-539.

https://doi.org/10.1016/j.theriogenology.2005.04.031

[90] Reed, D. and Orrenius, S. (1977) The Role of Methionine in Glutathione Biosynthesis by Isolated Hepatocytes. Biochemical and Biophysical Research Communications, 77, 1257-1264. https://doi.org/10.1016/S0006-291X(77)80115-0

[91] Wright, C.E., Tallan, H.H., Lin, Y.Y. and Gaull, G.E. (1986) Taurine: Biological Update. Annual Review of Biochemistry, 55, 427-453.

https://doi.org/10.1146/annurev.bi.55.070186.002235

[92] Foote, R.H., Brockett, C.C. and Kaproth, M.T. (2002) Motility and Fertility of Bull Sperm in Whole Milk Extender Containing Antioxidants. Animal Reproduction Science, 71, 13-23. https://doi.org/10.1016/S0378-4320(02)00018-0

[93] Huxtable, R.J. (1992) Actions of Taurine. Physiological Reviews, 72, 101-142. https://doi.org/10.1152/physrev.1992.72.1.101

[94] Lewis, S.E.M., Sterling, E.S.L., Young, I.S. and Thompson, W. (1997) Comparison of Individual Antioxidants of Sperm and Seminal Plasma in Fertile and Infertile Men. Fertility and Sterility, 67, 142-147. https://doi.org/10.1016/S0015-0282(97)81871-7

[95] Olsen, A., Siboska, G.E., Clark, B.F.C. and Rattan, S.I.S. (1999) N 6-Furfuryladenine, Kinetin, Protects against Fenton Reaction-Mediated Oxidative Damage to DNA. Biochemical and Biophysical Research Communications, 265, 499-502. https://doi.org/10.1006/bbrc.1999.1669

[96] Allai, L., Karym, E.M., El Amiri, B., Nasser, B., Essamad, A., Terzioğlu, P., Ertas, A. and Öztürk, M. (2017) Evaluation of Antioxidant Activity and Phenolic Composition of Opuntia ficus-indica Cladodes Collected from Moroccan Settat Region. Eurasian Journal of Analytical Chemistry, 12, 105-117. https://doi.org/10.12973/ejac.2017.00148a

[97] Mehr, M.R.-A. and Parisoush, P. (2016) Effect of Different Levels of Silymarin and Caproic Acid on Storage of Ram Semen in Liquid Form. Reproduction in Domestic Animals, 51, 569-574. https://doi.org/10.1111/rda.12721

[98] Fernandez-Bolanos, J., Lopez, O., Fernandez-Bolanos, J. and Rodriguez-Gutierrez, G. (2008) Hydroxytyrosol and Derivatives: Isolation, Synthesis, and Biological Properties. Current Organic Chemistry, 12, 442-463. https://doi.org/10.2174/138527208784083888

[99] Bermúdez-Oria, A., Rodríguez-Gutiérrez, G., Rodríguez-Juan, E., González-Benjumea, A. and Fernández-Bolaños, J. (2018) Molecular Interactions between 3,4-Dihy-Droxyphenylglycol and Pectin and Antioxidant Capacity of this Complex In Vitro. Carbohydrate Polymers, 197, 260-268. https://doi.org/10.1016/j.carbpol.2018.05.089

[100] Feugang, J.M., Konarski, P., Zou, D., Stintzing, F.C. and Zou, C. (2006) Nutritional and Medicinal Use of Cactus Pear (Opuntia spp.) Cladodes and Fruits. Frontiers in Bioscience, 11, 2574-2589. https://doi.org/10.2741/1992 
[101] Di Mascio, P., Kaiser, S. and Sies, H. (1989) Lycopene as the Most Efficient Biological Carotenoid Singlet Oxygen Quencher. Archives of Biochemistry and Biophysics, 274, 532-538. https://doi.org/10.1016/0003-9861(89)90467-0

[102] Lettéron, P., Labbe, G., Degott, C., Berson, A., Fromenty, B., Delaforge, M., Larrey, D. and Pessayre, D. (1990) Mechanism for the Protective Effects of Silymarin against Carbon Tetrachloride-Induced Lipid Peroxidation and Hepatotoxicity in Mice. Evidence That Silymarin Acts Both as an Inhibitor of Metabolic Activation and as a Chain-Breaking Antioxidant. Biochemical Pharmacology, 39, 2027-2034. https://doi.org/10.1016/0006-2952(90)90625-U

[103] Zi, X., Grasso, A.W., Kung, H.-J. and Agarwal, R. (1998) A Flavonoid Antioxidant, Silymarin, Inhibits Activation of erbBl Signaling and Induces Cyclin-Dependent Kinase Inhibitors, $\mathrm{G}_{1}$ Arrest, and Anticarcinogenic Effects in Human Prostate Carcinoma DU145 Cells. Cancer Research, 58, 1920-1929.

[104] Špaleková, E., Makarevich, A.V., Kubovičová, E., Ostró, A. and Chrenek, P. (2014) Effect of Caffeine on Functions of Cooling-Stored Ram Sperm in Vitro. ActaVeterinaria Brno, 83, 19-25. https://doi.org/10.2754/avb201483010019

[105] Pervaiz, S. and Holme, A.L. (2009) Resveratrol: Its Biologic Targets and Functional Activity. Antioxidants and Redox Signaling, 11, 2851-2897.

https://doi.org/10.1089/ars.2008.2412

[106] Li, C.Y., Zhao, Y.H., Hao, H.S., Wang, H.Y., Huang, J.M., Yan, C.L., Du, W.H., Pang, Y.W., Zhang, P.P., Liu, Y., Zhu, H.B. and Zhao, X.M. (2018) Resveratrol Significantly Improves the Fertilisation Capacity of Bovine Sex-sorted Semen by Inhibiting Apoptosis and Lipid Peroxidation. Scientific Reports, 8, Article No. 7603. https://doi.org/10.1038/s41598-018-25687-Z

[107] Al-Mutary, M.G., Al-Ghadi, M.Q., Ammari, A.A., Al-Himadi, A.R., Al-Jolimeed, A.H., Arafah, M.W., Amran, R.A., Aleissa, M.S. and Swelum, A.A.-A. (2020) Effect of Different Concentrations of Resveratrol on the Quality and in Vitro Fertilizing Ability of Ram Semen Stored at $5^{\circ} \mathrm{C}$ for up to $168 \mathrm{~h}$. Theriogenology, 152, 139-145. https://doi.org/10.1016/j.theriogenology.2020.05.001

[108] Yániz, J., Martí, J.I., Silvestre, M.A., Folch, J., Santolaria, P., Alabart, J.L. and López-Gatius, F. (2005) Effects of Solid Storage of Sheep Spermatozoa at $15^{\circ} \mathrm{C}$ on their Survival and Penetrating Capacity. Theriogenology, 64, 1844-1851. https://doi.org/10.1016/j.theriogenology.2005.04.012

[109] López-Gatius, F., Sances, G., Sancho, M., Yániz, J., Santolaria, P., Gutiérrez, R., Núñez, M., Núñez, J. and Soler, C. (2005) Effect of Solid Storage at $15^{\circ} \mathrm{C}$ on the Subsequent Motility and Fertility of Rabbit Semen. Theriogenology, 64, 252-260. https://doi.org/10.1016/j.theriogenology.2004.11.015

[110] Paulenz, H., Ådnøy, T., Fossen, O.H. and Söderquist, L. (2010) Effect on Field Fertility of Addition of Gelatine, Different Dilution Rates and Storage Times of Cooled Ram Semen after Vaginal Insemination. Reproduction in Domestic Animals, 45, 706-710. https://doi.org/10.1111/j.1439-0531.2008.01338.x

[111] Ashrafi, I., Kohram, H., Naijian, H., Bahreini, M. and Poorhamdollah, M. (2011) Protective Effect of Melatonin on Sperm Motility Parameters on Liquid Storage of Ram Semen at $5^{\circ} \mathrm{C}$. African Journal of Biotechnology, 10, 6670-6674.

[112] Dai, G.C., Meng, Y., Zhang, L.K., Du, Y.Q., Wen, F., Feng, T.Y. and Hu, J.H. (2019) Effect of Addition of Melatonin on Liquid Storage of Ram Semen at $4^{\circ} \mathrm{C}$. Andrologia, 51, e13236. https://doi.org/10.1111/and.13236

[113] Suno, M. and Nagaoka, A. (1984) Inhibition of Lipid Peroxidation by a Novel Compound, Idebenone (CV-2619). Japanese Journal of Pharmacology, 35, 196-198. 
https://doi.org/10.1016/S0021-5198(19)38088-6

[114] Eslami, M., Jahan-Roshan, V. and Farrokhi-Ardabili, F. (2019) Influence of Idebenone on Ram Semen Quality Stored at $4^{\circ}$ C. Reproduction in Domestic Animals, 54, 486-497. https://doi.org/10.1111/rda.13379

[115] Van Overveld, F.W.P.C., Haenen, G.R.M.M., Rhemrev, J., Vermeiden, J.P.W. and Bast, A. (2000) Tyrosine as Important Contributor to the Antioxidant Capacity of Seminal Plasma. Chemico-Biological Interactions, 127, 151-161. https://doi.org/10.1016/S0009-2797(00)00179-4

[116] Baran, A., Ak, K. and Soylu, M.K. (2004) Effects of Adding Bull Seminal Plasma to Ram Semen Extenders on Post-Thaw Spermatozoa Motility and Morphology. The Indian Veterinary Journal, 81, 780-783.

[117] Höfner, L., Luther, A.-M.andWaberski, D. (2020) The Role of Seminal Plasma in the Liquid Storage of Spermatozoa. Animal Reproduction Science, 220, Article ID: 106290. https://doi.org/10.1016/j.anireprosci.2020.106290

[118] Mata-Campuzano, M., Soleilhavoup, C., Tsikis, G., Martinez-Pastor, F., De Graaf, S.P. and Druart, X. (2015) Motility of Liquid Stored Ram Spermatozoa Is Altered by Dilution Rate Independent of Seminal Plasma Concentration. Animal Reproduction Science, 162, 31-36. https://doi.org/10.1016/j.anireprosci.2015.09.004

[119] Fukuhara, R. and Nishikawa, Y. (1973) Effects of pH, Sperm Concentration, Washing and Substrate Concentration on Respiration and Motility of Goat Spermatozoa. Nihon ChikusanGakkaiho, 44, 266-270. https://doi.org/10.2508/chikusan.44.266

[120] Aboagla, E.M.-E. and Tearada, T. (2003) Trehalose-Enhanced Fluidity of the Goat Sperm Membrane and Its Protection During Freezing. Biology of Reproduction, 69, 1245-1250. https://doi.org/10.1095/biolreprod.103.017889

[121] Jafaroghli, M., Khalili, B., Farshad, A. and Zamiri, M.J. (2011) The Effect of Supplementation of Cryopreservation Diluents with Sugars on the Post-Thawing Fertility of Ram Semen. Small Ruminant Research, 96, 58-63.

https://doi.org/10.1016/j.smallrumres.2010.11.010

[122] Liu, Z., Foote, R.H. and Brockett, C.C. (1998) Survival of Bull Sperm Frozen at Different Rates in Media Varying in Osmolarity. Cryobiology, 37, 219-230. https://doi.org/10.1006/cryo.1998.2117

[123] Martí, J.I., Martí, E., Cebrián-Pérez, J.A. and Muiño-Blanco, T. (2003) Survival Rate and Antioxidant Enzyme Activity of Ram Spermatozoa after Dilution with Different Extenders or Selection by a Dextran Swim-Up Procedure. Theriogenology, 60, 1025-1037. https://doi.org/10.1016/S0093-691X(03)00105-5

[124] Arando, A., Gonzalez, A., Delgado, J.V., Arrebola, F.A. and Perez-Marín, C.C. (2017) Storage Temperature and Sucrose Concentrations Affect Ram Sperm Quality after Vitrification. Animal Reproduction Science, 181, 175-185. https://doi.org/10.1016/j.anireprosci.2017.04.008

[125] Agca, Y., Gilmore, J., Byers, M., Woods, E.J., Liu, J. and Critser, J.K. (2002) Osmotic Characteristics of Mouse Spermatozoa in the Presence of Extenders and Sugars. Biology of Reproduction, 67, 1493-1501. https://doi.org/10.1095/biolreprod.102.005579

[126] White, I.G. (2006) Lipids and Calcium Uptake of Sperm in Relation to Cold Shock and Preservation: A Review. Reproduction, Fertility and Development, 5, 639-658. https://doi.org/10.1071/RD9930639

[127] Giraud, M.N., Motta, C., Boucher, D. and Grizard, G. (2000) Membrane Fluidity Predicts the Outcome of Cryopreservation of Human Spermatozoa. Human Reproduction, 15, 2160-2164. https://doi.org/10.1093/humrep/15.10.2160 
[128] Hashem, E.Z., Haddad, R. and Eslami, M. (2017) Evaluation of Ram Semen Enrichment with Oleic Acid on Different Spermatozoa Parameters during Low Temperature Liquid Storage. Small Ruminant Research, 150, 30-39. https://doi.org/10.1016/j.smallrumres.2017.03.002

[129] Rateb, S.A. (2018) Influence of Omega-3 Incorporation in Sperm Preservation Medium on Physical and Kinematic Properties of Chilled and Cryopreserved Ram Spermatozoa. Reproduction in Domestic Animals, 53, 1506-1516. https://doi.org/10.1111/rda.13289

[130] Falchi, L., Khalil, W.A., Hassan, M. and Marei, W.F.A. (2018) Perspectives of Nanotechnology in Male Fertility and Sperm Function. International Journal of Veterinary Science and Medicine, 6, 265-269. https://doi.org/10.1016/j.ijvsm.2018.09.001

[131] Stevanović, M., Bračko, I., Milenković, M., Filipović, N., Nunić, J., Filipič, M. and Uskoković, D.P. (2014) Multifunctional PLGA Particles Containing Poly(l-glutamic acid)-Capped Silver Nanoparticles and Ascorbic Acid with Simultaneous Antioxidative and Prolonged Antimicrobial Activity. Acta Biomaterialia, 10, 151-162. https://doi.org/10.1016/j.actbio.2013.08.030

[132] Lee, G.H., Lee, S.J., Jeong, S.W., Kim, H.C., Park, G.Y., Lee, S.G. and Choi, J.H. (2016) Antioxidative and Antiinflammatory Activities of Quercetin-loaded Silica Nanoparticles. Colloids and Surfaces B: Biointerfaces, 143, 511-517. https://doi.org/10.1016/j.colsurfb.2016.03.060

[133] Kim, A., Ha, J.H. and Park, S.N. (2017) Selective Release System for Antioxidative and Anti-Inflammatory Activities Using $\mathrm{H}_{2} \mathrm{O}_{2}$-Responsive Therapeutic Nanoparticles. Biomacromolecules, 18, 3197-3206. https://doi.org/10.1021/acs.biomac.7b00844

[134] Barkalina, N., Jones, C., Kashir, J., Coote, S., Huang, X., Morrison, R., Townley, H. andCoward, K. (2014) Effects of Mesoporous Silica Nanoparticles upon the Function of Mammalian Sperm In Vitro. Nanomedicine: Nanotechnology, Biology, and Medicine, 10, 859-870. https://doi.org/10.1016/j.nano.2013.10.011 